\title{
Apostila ilustrada de cirurgia veterinária
}

\section{Renata Resende $\operatorname{Prado}^{l}$; Eliane Pereira Mendonça ${ }^{1,2}$; Guilherme Paz Monteiro ${ }^{1,2}$; Roberta Torres de Melo ${ }^{1,2}$; Daise Aparecida Rossi ${ }^{1,2}$}

${ }^{1}$ Laboratório de Biotecnologia Animal Aplicada. ${ }^{2}$ Programa de Pós-Graduação em Ciências Veterinárias

RESUMO: Este material-didático é uma apostila ilustrada de cirurgia que tem a função de oferecer suporte de consulta ao aprendiz de Cirurgia Veterinária, abordando os tópicos: Instrumentalização Cirúrgica, Materiais de Sutura, Princípios Cirúrgicos Gerais, Incisões Cirúrgicas da Parede do Abdome e Suturas Usadas na Medicina Veterinária.

Palavras-chave: Apostila. Cirurgia. Medicina Veterinária

\section{Illustrated Textbook of Veterinary Surgery}

ABSTRACT: This material is an illustrated textbook of surgery that has the function to offer consultation support to the learner of Veterinary Surgery, addressing the topics: Instrumentalization Surgical, Suture Materials, Surgical General Principles, Surgical Incisions of the Abdominal Wall and Sutures Used in Veterinary Medicine.

Keywords: Textbook. Surgery. Veterinary Medicine.

\section{INSTRUMENTAÇÃO CIRÚRGICA}

Instrumentos cirúrgicos mais utilizados na rotina cirúrgica veterinária:

\section{BISTURI}

Os bisturis são os instrumentos de corte primário utilizados para realizar incisões nos tecidos. O bisturi deve ser aplicado na divisão exata do tecido causando a menor lesão possível às estruturas vizinhas. Hoje, as lâminas de bisturi apresentam uma variedade de tamanhos e formas, cada uma desenhada para uma finalidade específica. Na medicina veterinária, cabos de bisturi reutilizáveis com lâminas descartáveis são mais utilizados. Os cabos de bisturi têm diferentes tamanhos, sendo que os de número $3 \mathrm{e}$ 4 são geralmente adequados para a maioria dos procedimentos cirúrgicos. Diversos tipos de lâminas e cabos de bisturi encontram-se ilustrados na figura 1 .
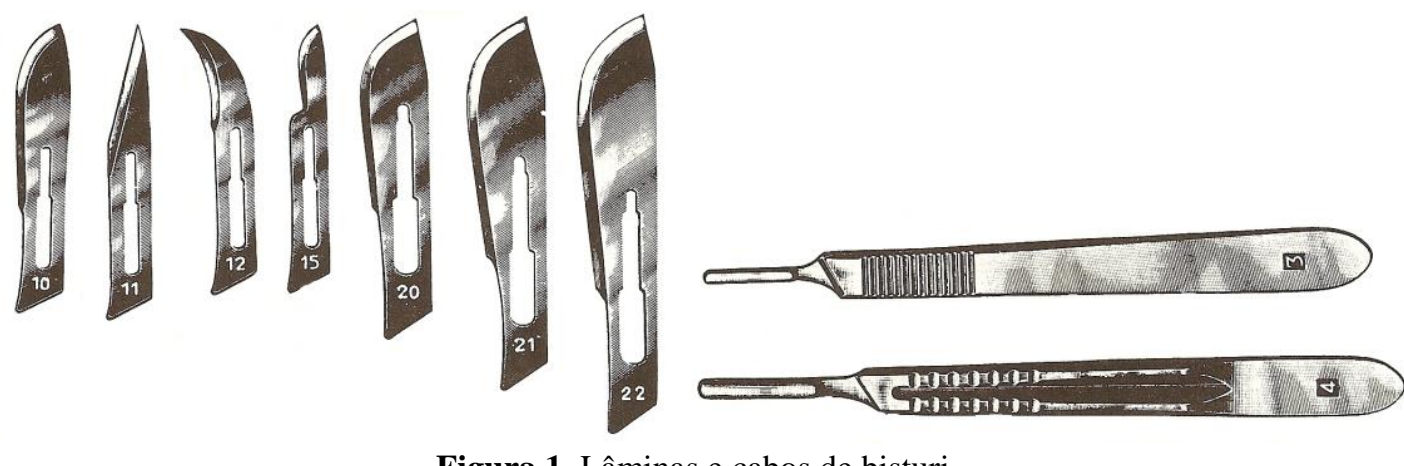

Figura 1. Lâminas e cabos de bisturi.

Deve-se segurar o bisturi na palma da mão de maneira que fique sempre sob controle. Ele é preso pelo dedo polegar e pelo terceiro e quarto dedos, sendo que o indicador fica posicionado 
por cima, sobre a união da lâmina com o cabo (Figura 2). Nunca segurá-lo como se fosse um lápis ou uma pinça de dedo. Para cortar, faça um movimento contínuo com a porção arredondada da lâmina, isto é, com a "barriga" e não com a ponta. A quantidade de pressão a ser aplicada varia, mas a intenção é de produzir uma incisão nítida, única, e de espessura íntegra na pele com apenas um movimento contínuo da lâmina.
Quando a lâmina do bisturi torna-se obtusa deve-se removê-la cuidadosamente agarrando-a com um porta-agulhas ou uma pinça hemostática (Figura3).

Para retirar uma lâmina nova do seu pacote, o auxiliar de cirurgia abre o mesmo expondo para fora a extremidade da lâmina. Entra-se em contato apenas com a lâmina tomando o cuidado para arrancá-la do pacote, evitando romper a técnica asséptica (Figura 4).

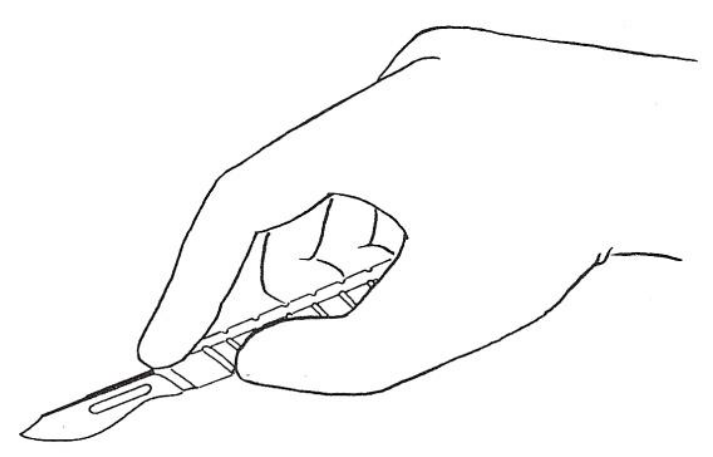

Figura 2. Maneira correta de segurar o bisturi.

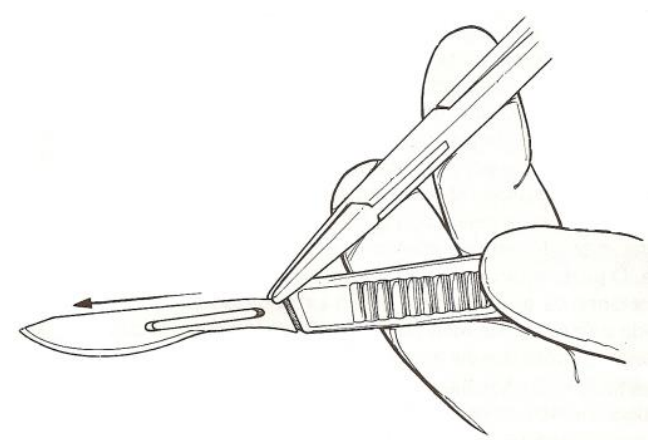

Figura 3. Remoção da lâmina do cabo do bisturi.

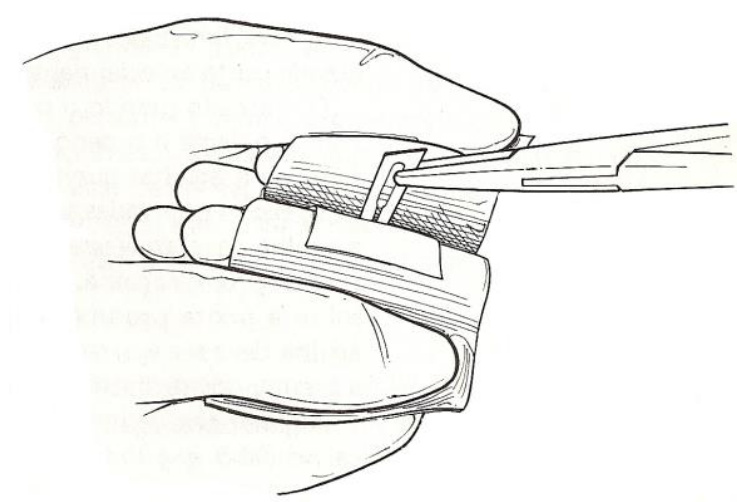

Figura 4. Técnica asséptica de manuseio da lâmina nova.

\section{PINÇAS DE TECIDO}

A pinça de tecido é utilizada para agarrar e segurar os tecidos. Ela é firmada pelo polegar, dedo médio e indicador. Podem ser pontiagudas, achatadas, arredondadas, lisas ou serrilhadas, ou apresentar dentes pequenos ou grandes (Figura 5). Geralmente, essas pinças são usadas na mão 
não-dominante. Elas devem ser usadas de maneira que uma das lâminas funcione como extensão do polegar e a outra como extensão dos dedos oponentes (ou seja, posição de lápis) (Figura 6).

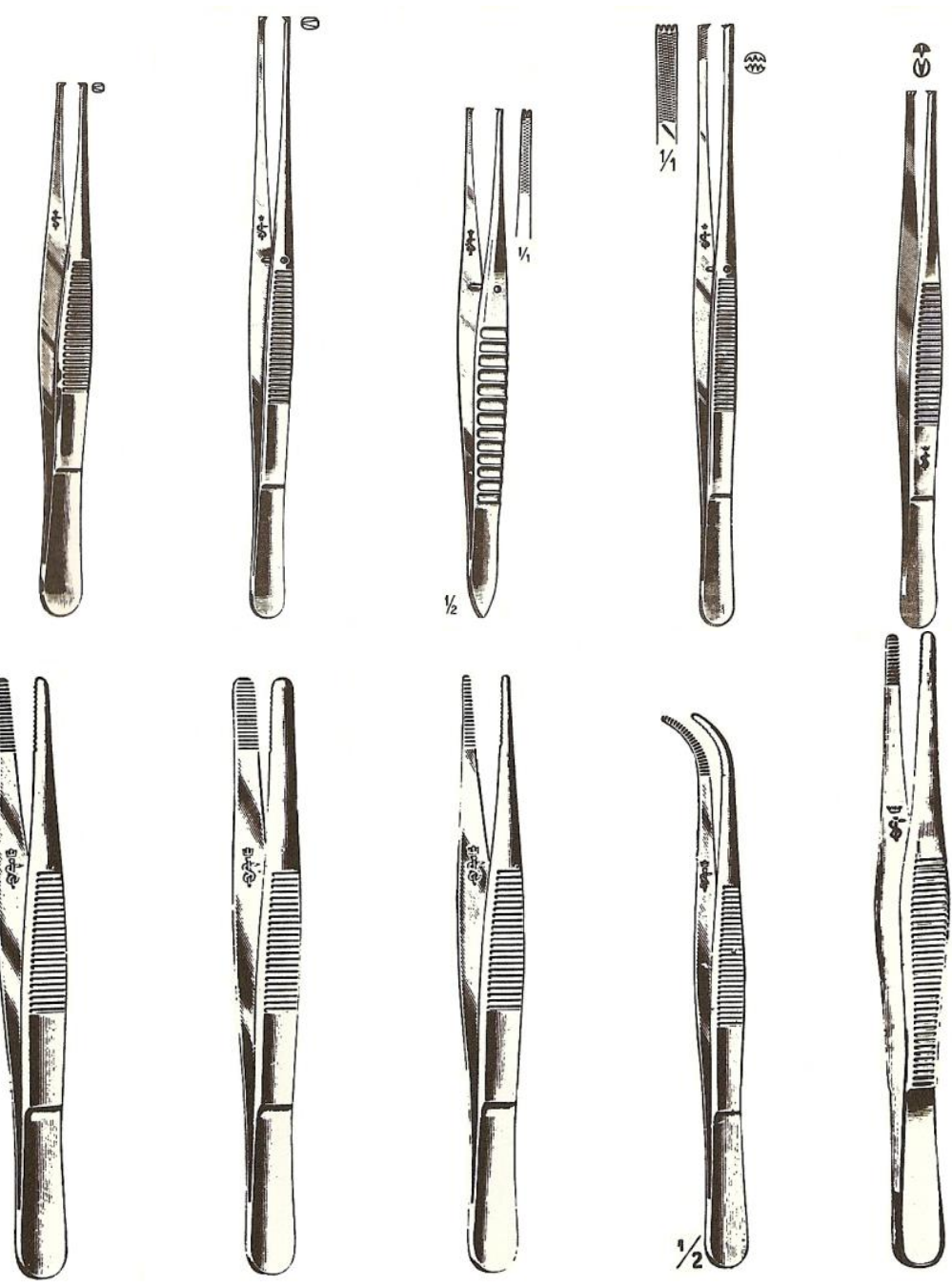

Figura 5. Pinças de tecido.

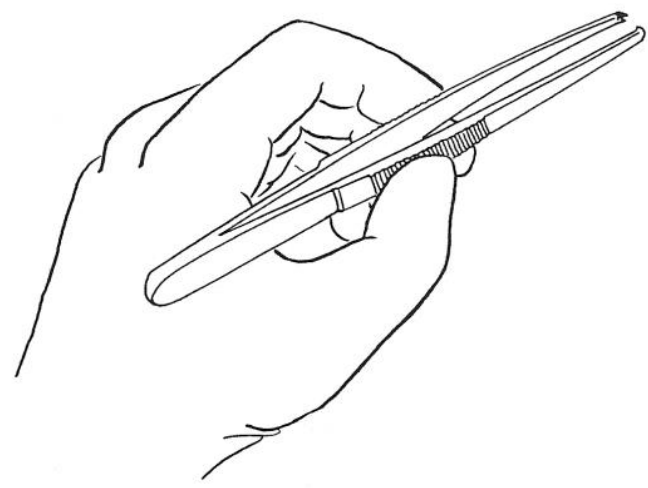

Figura 6. Maneira correta de segurar a pinça.

\section{PINÇAS HEMOSTÁTICAS}

Pinças hemostáticas são instrumentos usados para pinçar vasos sanguíneos, sendo empregadas para ocluir as extremidades dos vasos e deste modo estabelecer a hemostasia. Encontram-se disponíveis com pontas retas ou curvas e em tamanhos variados (Figura 7). A pinça 
hemostática mosquito de Halsted é utilizada no controle de pequenos pontos de hemorragia e possuem serrilhas de lâminas transversais. As serrilhas das lâminas das pinças hemostáticas maiores podem ser transversais, longitudinais, diagonais ou uma combinação desses tipos. As serrilhas geralmente se estendem desde as pontas das lâminas até as travas, mas, no caso das pinças de Kelly, as transversais se estendem somente pela porção distal das lâminas. As pinças de Crile possuem serrilhas transversais que se estendem por todo o comprimento da lâmina. As pinças de Kelly e de Crile são usadas em vasos maiores. As pinças hemostáticas de Rochester-Carmalt são pinças esmagadoras maiores, que são usadas frequentemente para controlar grandes feixes teciduais e também na ligação de cotos e pedículos. Elas possuem sulcos longitudinais com sulcos cruzados nas extremidades das pontas para evitar deslizamento tecidual. A Figura 8 mostra como deve ser usado o instrumento.
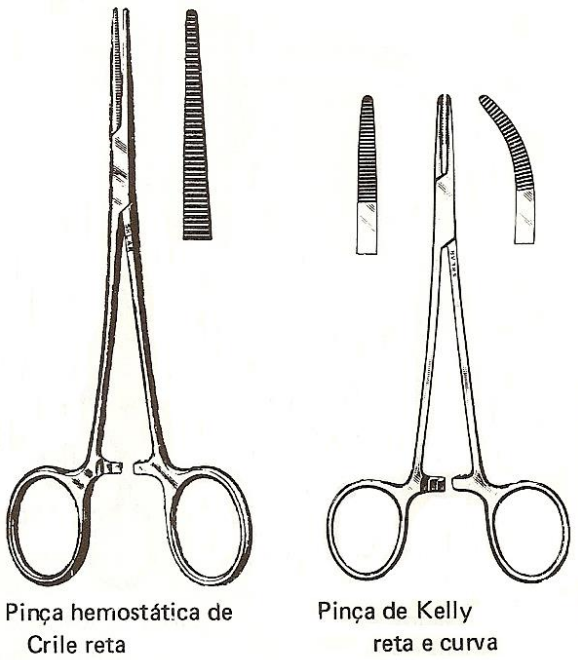

Figura 7. Pinças hemostáticas.
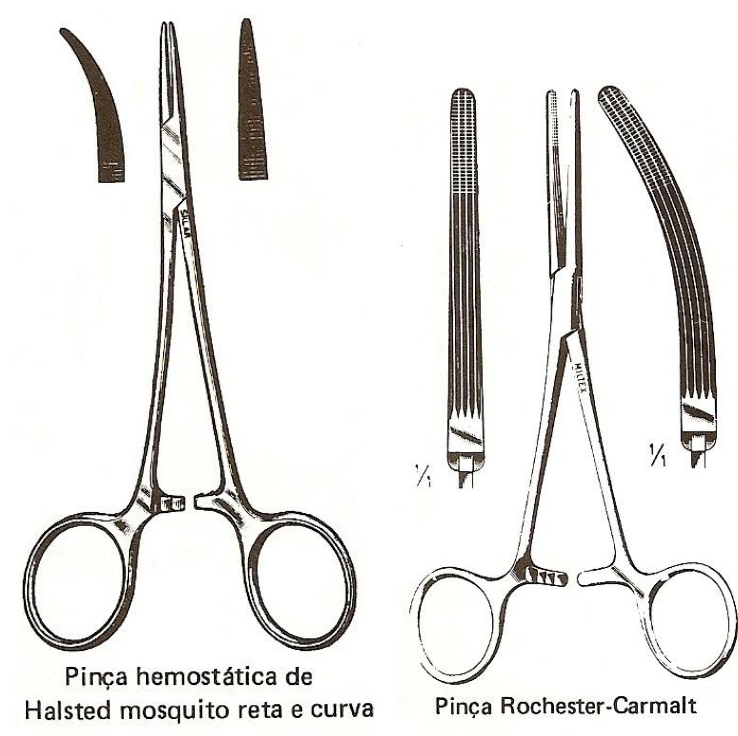

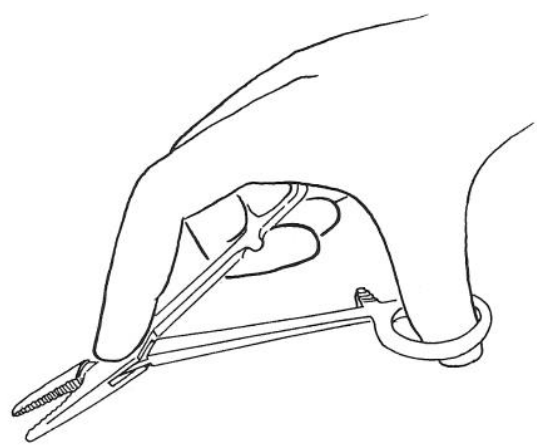

Figura 8. Maneira correta de segurar a pinça hemostática.

\section{PORTA-AGULHAS}

Os porta-agulhas são usados para pegar e manipular agulhas curvas. As agulhas retas devem ser presas somente pela mão, sendo reservadas apenas para a pele e o intestino. $\mathrm{O}$ tamanho e o tipo do porta-agulha são determinados pelas características da agulha a ser usada e da localização do tecido a ser suturado. Agulhas mais pesadas e maiores exigem portaagulhas denteados, mais pesados e mais largos. A maior parte dos porta-agulhas apresentam uma trava com catraca distal ao polegar (por exemplo, de Mayo-Hegar, de Olsen-Hegar), mas alguns apresentam um mecanismo de mola e ferrolho para travamento (por exemplo, de Mathieu) (Figura 9). Na medicina veterinária, os portaagulhas de Mayo-Hegar são comumente usados quando são manipuladas agulhas médias a grossas. Os porta-agulhas de Olsen-Hegar são usados de modo semelhante, mas possuem lâminas de tesoura que permitem amarrar e cortar o fio de sutura com o mesmo instrumento (porta agulhas combinado com tesoura para incisão). 
Sua desvantagem é a necessidade de cuidados para evitar cortar o fio de sutura durante a amarração. Os porta-agulhas de Mathieu têm uma trava com catraca na extremidade proximal dos cabos, o que permite travamento e destravamento por meio de um aperto conjunto e progressivo de seus cabos. Com o porta agulhas, a agulha deve atravessar o tecido em movimento de arco, seguindo a curvatura da própria agulha. O porta agulhas é então retirado e depois recolocado sobre a ponta protuberante da agulha, que é então extraída do tecido. A agulha deve ser agarrada pela sua parte mais espessa e não pela ponta, já que a ponta pode ser facilmente entortada ou quebrada.
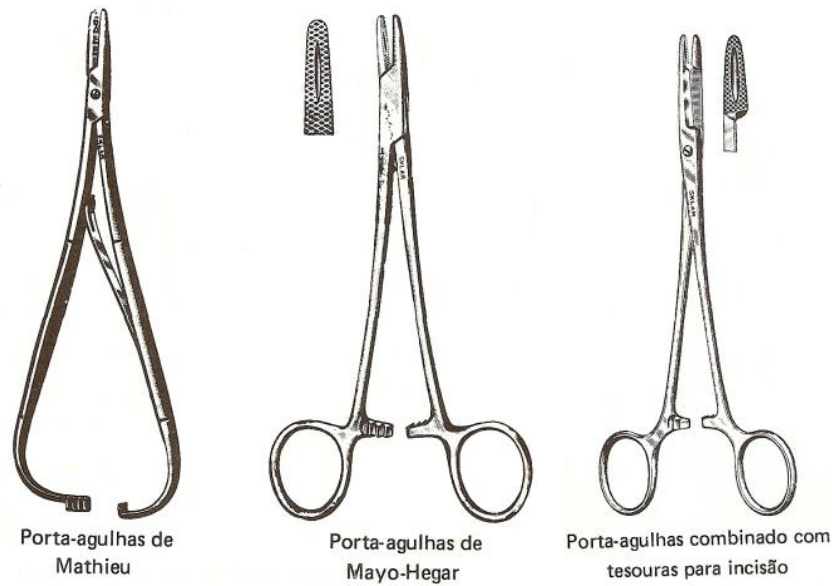

Figura 9. Porta-agulhas.

Porta-agulhas podem ser segurados por uma pegada com a palma, em que não se coloca nenhum dedo nos aros sendo que o aro superior deve repousar contra a base do polegar (Figura 10), uma pegada tenar (o aro superior repousa sobre a base do polegar e o dedo anular se insere

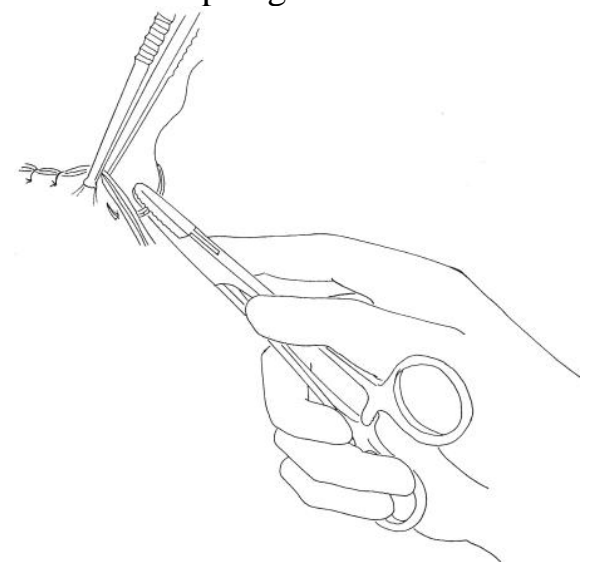

Figura 10. Pegada com a palma.

\section{TESOURAS}

As tesouras possuem várias formas, tamanhos e pesos e são classificadas de acordo com o tipo da ponta (por exemplo, romba-romba, afiadaafiada, afiada-romba), a forma da lâmina (por exemplo, reta, curva) ou a borda de corte (simples, serrilhada) (Figura 12). As tesouras retas são utilizadas para trabalhar próximo à superfície do ferimento enquanto se trabalha nas no aro inferior), uma pegada polegar-anular, em que o polegar deve ser posicionado no aro superior e o anular no aro inferior (Figura 11) ou uma "pegada de lápis" (o indicador e o polegar repousam sobre o corpo do porta-agulha), que é usada para porta-agulhas de Mathieu.

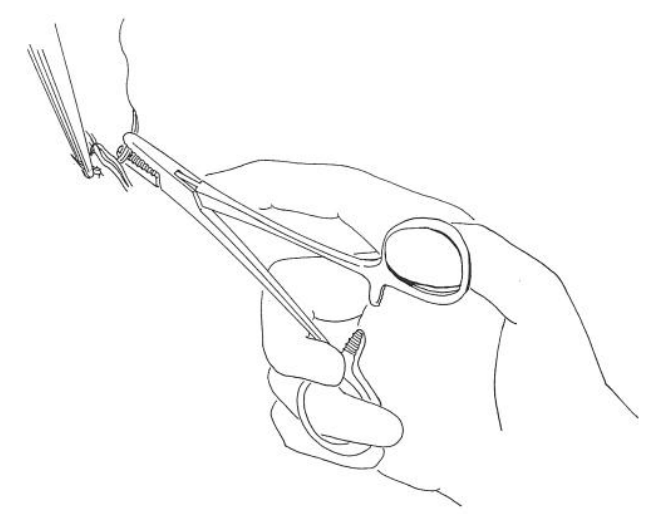

Figura 11. Pegada polegar-anular.

partes mais profundas com as tesouras curvas. Dispõem-se então de uma variedade de tesouras que são empregadas em procedimentos tais como, incisão de tecidos ou dissecação entre os planos teciduais. De uma maneira geral, as tesouras para corte de tecidos são leves e precisas. As tesouras precisam ser mantidas sempre afiadas, caso contrário não irão cortar os tecidos adequadamente. 
Segura-se a tesoura posicionando o polegar e o anular através dos aros digitais, com o dedo indicador repousando sobre o corpo da tesoura (Figura 13).
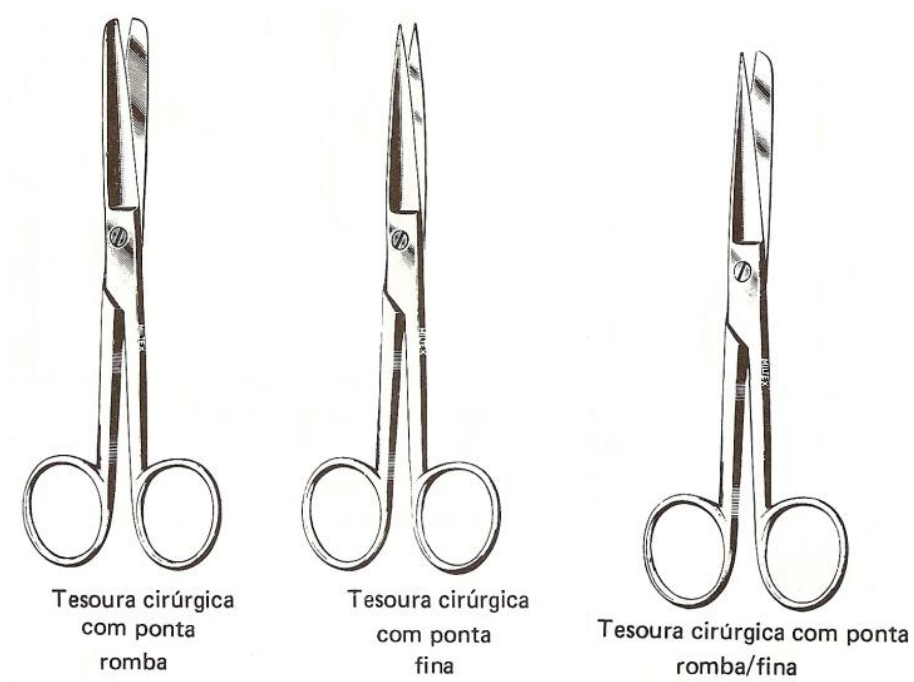

Figura 12. Tesouras cirúrgicas.

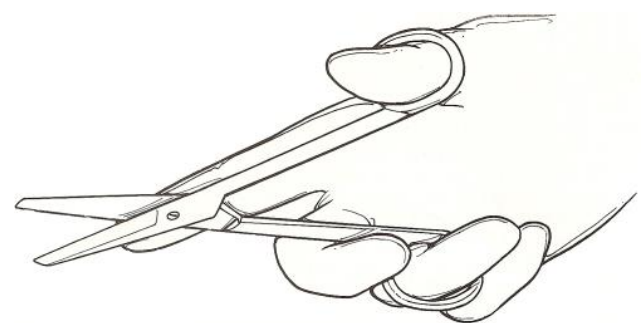

Figura 13. Maneira correta de segurar a tesoura.

\section{PINÇAS TECIDUAIS ESPECIAIS}

Essas pinças são próprias para porções maiores de tecido, mantendo-os presos com o uso de um dispositivo de alavanca localizado no cabo. Encontram-se disponíveis pinças teciduais de vários tamanhos e formas para vários usos (Figura 14). Exemplos:

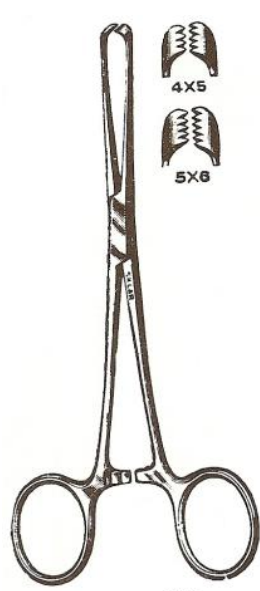

Pinça de Allis

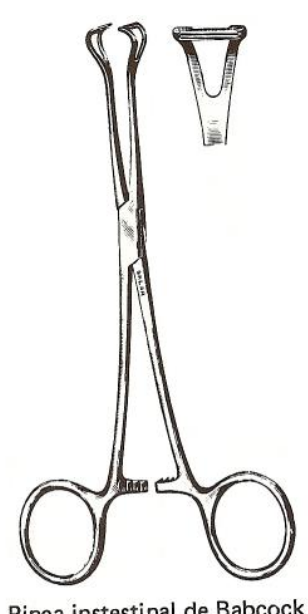

Pinça instestinal de Babcock
- Pinça tecidual de Allis.

- Pinça intestinal de Babcock.

- Pinça intestinal de Doyen.

- Pinça de ducto biliar de Lahey.

Figura 14. Pinças teciduais especiais.
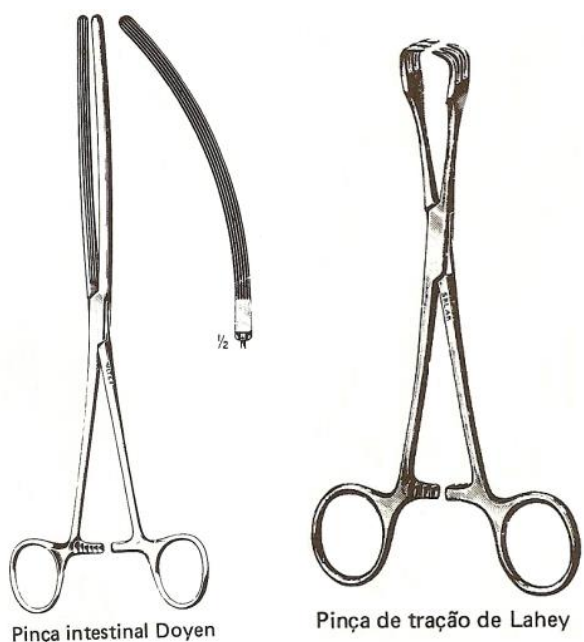

Pinça de tração de Lahey 


\section{PINÇAS DE CAMPO}

São projetadas para prender panos de campo à diferentes de pinças de campo, dentre elas a de pele. Encontram-se disponíveis vários estilos

Backhaus, Roeder e Jones (Figura 15).

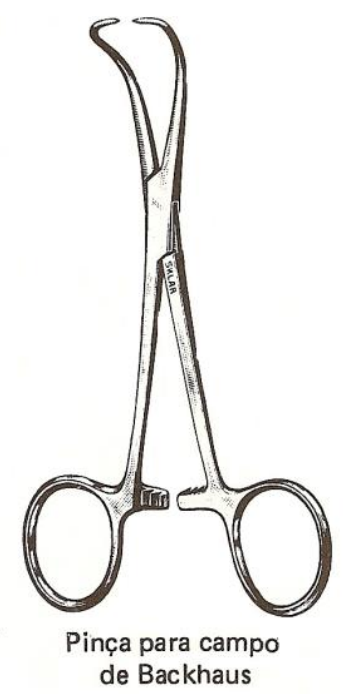

Figura 15. Pinça de campo.

\section{AFASTADORES}

Os afastadores funcionam no sentido de afastar os tecidos para que o cirurgião possa visualizar mais adequadamente o campo cirúrgico. Classificam-se em: afastadores digitais, afastadores manuais e afastadores auto-ajustáveis (Figura 16).
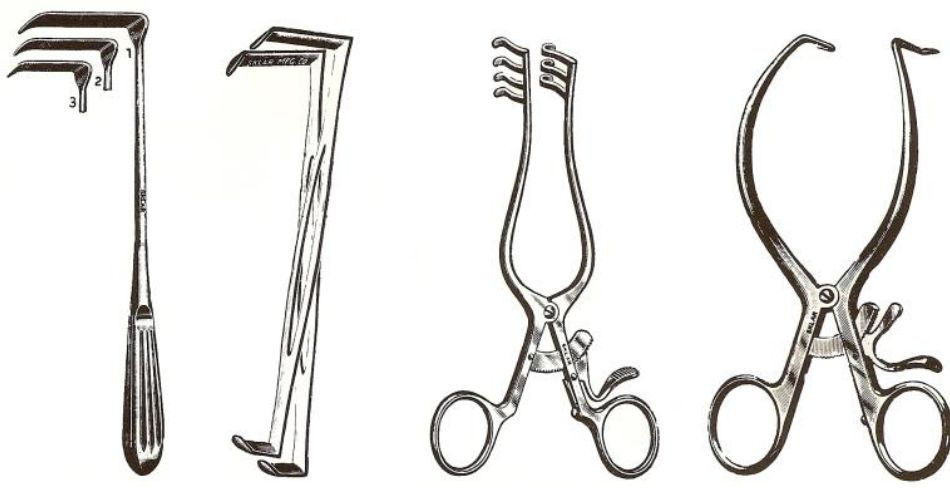

Figura16. Afastadores.

\section{MATERIAIS DE SUTURA}

\section{CARACTERÍSTICAS DOS FIOS DE SUTURA}

Um fio de sutura ideal é fácil de manipular, reage minimamente com o tecido, inibe o crescimento bacteriano, se mantém seguro quando amarrado com nó, resiste a encolhimento nos tecidos, não é capilar, alergênico, carcinogênico nem ferromagnético e é absorvido com mínima reação após a cicatrização do tecido. Infelizmente, tal fio de sutura ideal não existe e, portanto, os cirurgiões devem escolher aquele que mais se aproxima do ideal para um determinado procedimento e tecido a ser suturado. Encontra-se disponível uma ampla variedade de combinações de fios de sutura como pode ser visto na Tabela 1.

Os materiais de sutura podem ser classificados de acordo com seu comportamento no tecido (absorvíveis ou não-absorvíveis), sua estrutura (monofilamentares ou multifilamentares) ou sua origem (sintéticos, orgânicos ou metálicos). Os fios de sutura monofilamentares são fabricados com um único fio de material. Eles apresentam 
menos arrasto tecidual que os materiais multifilamentares e não possuem interstícios que possam abrigar bactérias. Deve-se ter cuidado ao manipular fios de sutura monofilamentares, pois um corte ou dano com pinças ou porta-agulhas os enfraquece e os predispõe a rupturas.

Tabela 1. Características gerais dos materiais de sutura.

\begin{tabular}{|c|c|c|c|c|}
\hline Nome genérico & Nome comercial & $\begin{array}{c}\text { Características do fio } \\
\text { de sutura }\end{array}$ & $\begin{array}{c}\text { Redução da força } \\
\text { tênsil }\end{array}$ & $\begin{array}{l}\text { Absorção } \\
\text { completa }\end{array}$ \\
\hline Categute cromado & Categute Softgut & $\begin{array}{c}\text { Absorvível } \\
\text { Multifilamentar }\end{array}$ & $\begin{array}{l}33 \% \text { em } 7 \text { dias } \\
67 \% \text { em } 28 \text { dias }\end{array}$ & 60 dias \\
\hline Poliglactina 910 & Vicryl & $\begin{array}{c}\text { Absorvível } \\
\text { Multifilamentar }\end{array}$ & $\begin{array}{l}35 \% \text { a } 50 \% \text { em } 14 \text { dias } \\
60 \% \text { a } 80 \% \text { em } 31 \text { dias }\end{array}$ & $60-90$ dias \\
\hline Ácido poliglicólico & Dexon & $\begin{array}{c}\text { Absorvível } \\
\text { Multifilamentar }\end{array}$ & $\begin{array}{l}35 \% \text { em } 14 \text { dias } \\
65 \% \text { em } 21 \text { dias }\end{array}$ & 120 dias \\
\hline Polidioxanona & PDS & $\begin{array}{c}\text { Absorvível } \\
\text { Monofilamentar }\end{array}$ & $\begin{array}{l}14 \% \text { em } 14 \text { dias } \\
31 \% \text { em } 42 \text { dias }\end{array}$ & 180 dias \\
\hline Poligliconato & Maxon & $\begin{array}{c}\text { Absorvível } \\
\text { Monofilamentar }\end{array}$ & $\begin{array}{l}30 \% \text { em } 14 \text { dias } \\
45 \% \text { em } 21 \text { dias }\end{array}$ & 180 dias \\
\hline \multirow{2}{*}{$\begin{array}{l}\text { Poliglecaprona } 25 \\
\text { Seda }\end{array}$} & Monocryl & $\begin{array}{c}\text { Absorvível } \\
\text { Monofilamentar }\end{array}$ & $\begin{array}{l}40 \% \text { a } 50 \% \text { em } 7 \text { dias } \\
70 \% \text { a } 80 \% \text { em } 14 \text { dias }\end{array}$ & $90-120$ dias \\
\hline & Perma-Hand & $\begin{array}{l}\text { Não-absorvível } \\
\text { Multifilamentar }\end{array}$ & $\begin{array}{l}30 \% \text { em } 14 \text { dias } \\
50 \% \text { em } 1 \text { ano }\end{array}$ & $>2$ anos \\
\hline Poliéster & $\begin{array}{l}\text { Mersiline } \\
\text { Dacron } \\
\text { Ethibond } \\
\text { Ticron }\end{array}$ & $\begin{array}{l}\text { Não-absorvível } \\
\text { Multifilamentar }\end{array}$ & - & - \\
\hline $\begin{array}{l}\text { Poliamida } \\
\text { (Náilon) }\end{array}$ & $\begin{array}{l}\text { Ethilon } \\
\text { Dermalon } \\
\text { Nurolon } \\
\text { Surgilon }\end{array}$ & $\begin{array}{l}\text { Não-absorvível } \\
\text { Monofilamentar } \\
\text { Multifilamentar }\end{array}$ & $\begin{array}{l}30 \% \text { em } 2 \text { anos } \\
\text { (monofilamentar) } \\
75 \% \text { em } 180 \text { dias } \\
\text { (multifilamentar) }\end{array}$ & - \\
\hline Polipropileno & $\begin{array}{l}\text { Prolene } \\
\text { Surgilene } \\
\text { Fluorofil }\end{array}$ & $\begin{array}{l}\text { Não-absorvível } \\
\text { Monofilamentar }\end{array}$ & - & - \\
\hline Polibutéster & Novafil & $\begin{array}{l}\text { Não-absorvível } \\
\text { Monofilamentar }\end{array}$ & - & - \\
\hline Caprolactama & $\begin{array}{c}\text { Supramid } \\
\text { Braunamid } \\
\text { Vetcassette II } \\
\text { Vetafil }\end{array}$ & $\begin{array}{l}\text { Não-absorvível } \\
\text { Multifilamentar }\end{array}$ & - & - \\
\hline $\begin{array}{l}\text { Fio de aço } \\
\text { inoxidável }\end{array}$ & Flexon & $\begin{array}{l}\text { Não-absorvível } \\
\text { Monofilamentar } \\
\text { Multifilamentar }\end{array}$ & - & - \\
\hline Algodão cirúrgico & - & $\begin{array}{l}\text { Não-absorvível } \\
\text { Multifilamentar }\end{array}$ & $50 \%$ em 180 dias & - \\
\hline Linho cirúrgico & - & $\begin{array}{l}\text { Não-absorvível } \\
\text { Multifilamentar }\end{array}$ & $70 \%$ em 2 anos & - \\
\hline Colágeno & - & $\begin{array}{l}\text { Não-absorvível } \\
\text { Multifilamentar }\end{array}$ & $50 \%$ em 120 dias & - \\
\hline \multirow{2}{*}{ Polietileno } & Colágeno & $\begin{array}{c}\text { Absorvível } \\
\text { Multifilamentar }\end{array}$ & - & 60 dias \\
\hline & Polyethilene & $\begin{array}{l}\text { Não-absorvível } \\
\text { Monofilamentar }\end{array}$ & $\begin{array}{c}\text { Perda lenta com o } \\
\text { passar dos anos }\end{array}$ & - \\
\hline
\end{tabular}


Os fios de sutura multifilamentares consistem de vários fios torcidos ou trançados juntos. Eles são mais maleáveis e flexíveis que os monofilamentares. Podem ser revestidos para diminuir o arrasto tecidual e potencializar as características de manipulação.

Materiais orgânicos absorvíveis: intestino cirúrgico (categute cromado), colágeno.

Materiais sintéticos absorvíveis: ácido poliglicólico, poliglactina 910, polidioxanona, poligliconato, poliglecaprona 25 .

Materiais orgânicos não-absorvíveis: algodão, linho e outras fibras vegetais (usados no passado), seda (usada atualmente).

Materiais sintéticos não-absorvíveis: poliamida, polibutéster, poliéster, polietileno, polipropileno, caprolactama.

Fio de sutura metálico: aço inoxidável.

\section{ESCOLHA E USO DOS MATERIAIS DE SUTURA}

Os materiais de sutura são classificados de várias formas para facilitar a discussão de suas características e seu uso, tais como de acordo com as características de absorção, número de filamentos, características capilares e origem das fibras. Não existe uma única sutura ideal para cada situação cirúrgica. No entanto, determinados materiais de sutura são melhor apropriados para ambientes de ferimentos diferentes. Ao se escolher um material de sutura, devem-se considerar certos princípios gerais.

\section{Força do tecido}

Uma sutura deve ser pelo menos tão forte quanto o tecido através do qual ela passa. A capacidade do tecido em segurar as suturas sem se romper depende de sua força (teor de colágeno) e da orientação das fibrilas de colágeno. A pele e as fáscias são os mais fortes, os músculos são relativamente fracos e a gordura é a mais fraca. Em geral, os tecidos viscerais se situam entre a gordura e os músculos quanto à força. A força do órgão varia dentro do mesmo órgão e também com a idade e o tamanho do animal.

\section{Força tênsil do nó}

A força tênsil do nó é medida pela força (em quilogramas) que o fio de sutura consegue suportar antes de se romper quando ligado com nó. Os fios de sutura devem ser tão fortes quanto o tecido através do qual estão sendo aplicados. No entanto, a força tênsil do fio não deve exceder em muito a do tecido.

\section{Tamanho do fio de sutura}

Deve-se usar o fio de menor diâmetro que segure adequadamente o tecido ferido, para minimizar o traumatismo à medida que o fio de sutura passa através do tecido e para diminuir a quantidade de material estranho no ferimento. Um fio de sutura não precisa ser mais forte que o tecido suturado. Desta forma, a escolha do tamanho do fio de sutura (Tabela 2) se baseia na força tênsil do tecido, bem como na do material de sutura. Os parâmetros para a utilização e o tamanho dos fios de sutura para vários tecidos se encontram resumidos na Tabela 3 . $O$ uso do menor tamanho possível de sutura para o fechamento de um ferimento resulta em menor traumatismo tecidual, permite que se dê nós menores e força o cirurgião a manipular mais cuidadosamente as suturas e o tecido. As suturas muito grandes podem na verdade enfraquecer o ferimento por meio de uma reação e um estrangulamento tecidual excessivo.

\section{Flexibilidade}

A flexibilidade de um fio de sutura é determinada por sua rigidez e seu diâmetro em torção, que influenciam sua manipulação e seu uso. Fios flexíveis são indicados para ligar vasos ou realizar padrões contínuos de sutura. Não se pode usar fios de sutura menos flexíveis (por exemplo, de aço) para ligar vasos pequenos. $\mathrm{O}$ náilon e o categute cirúrgico são relativamente rígidos em comparação ao fio de seda; os fios de poliéster trançados têm rigidez intermediária.

\section{Capilaridade}

A capilaridade é o processo pelo qual fluidos e bactérias são transportados para o interior dos interstícios das fibras multifilamentares. Como neutrófilos e macrófagos são muito grandes para entrarem nos interstícios das fibras, bactérias ficam aí abrigadas, criando uma barreira eficiente para a fagocitose, persistindo assim a infecção (particularmente em fios de sutura nãoabsorvíveis). Todos os materiais trançados (por exemplo, seda) são capilares; fios de sutura monofilamentares são menos capilares. $\mathrm{O}$ revestimento reduz a capilaridade de alguns fios de sutura. Não se deve usar materiais de sutura capilares em locais contaminados ou infectados. 


\section{Características superficiais e revestimento}

As características superficiais de um fio de sutura influenciam a facilidade com que ele é puxado através dos tecidos (ou seja, intensidade de atrito ou "arrasto") e a intensidade do traumatismo que isso causa. Fios de sutura ásperos causam mais lesão que os lisos. Superfícies lisas são particularmente importantes em tecidos delicados, tais como os olhos. No entanto, fios com superfícies lisas também apresentam desvantagens: exigem maior tensão para assegurar boa aproximação tecidual e apresentam menos segurança do nó. Materiais trançados quase sempre apresentam mais arrasto que fios de sutura monofilamentares. Eles também são frequentemente revestidos para diminuir a capilaridade e providenciar uma superfície lisa. As substâncias usadas para revestir fios de sutura incluem Teflon, silicone, cera, parafina-cera e estearato de cálcio.

\section{Perda de força da sutura e ganho de força do ferimento}

A perda de força da sutura deve ser proporcional ao ganho previsto na força do ferimento. As taxas relativas de perda de força da sutura e de ganho de força simultâneo do ferimento são importantes. As fáscias, os tendões e os ligamentos cicatrizam lentamente $(50 \%$ de ganho de força em 50 dias) e estão sob constante força tênsil. No caso desses tecidos, indicam-se suturas não-absorvíveis ou as mais recentes suturas absorvíveis sintéticas de degradação lenta. Como os ferimentos viscerais se cicatrizam com relativa rapidez, atingindo frequentemente a maior parte de sua força em 21 dias, tornam-se adequadas as suturas absorvíveis. As suturas nãoabsorvíveis monofilamentares são sugeridas para o fechamento da pele por induzirem uma menor resposta de corpo estranho e pela pele apresentar um ganho relativamente lento na força de cicatrização. Também deve-se considerar os fatores gerais e locais que afetam a cicatrização do ferimento antes de se escolher uma sutura apropriada. Por exemplo, o categute na presença de uma infecção ou de enzimas gástricas ou colocado em um paciente em catabolismo pode ser degradado dentro de alguns dias, deixando o fechamento do ferimento susceptível a uma deiscência.

Tabela 2. Tamanhos de fios de sutura.

\begin{tabular}{ccc}
\hline $\begin{array}{c}\text { Tamanho Real } \\
(\mathbf{M m})\end{array}$ & $\begin{array}{c}\text { Materiais De Sutura } \\
\text { Sintéticos (Usp) }\end{array}$ & $\begin{array}{c}\text { Categute Cirúrgico } \\
(\text { Usp) }\end{array}$ \\
\hline 0,02 & $10-0$ & - \\
0,03 & $9-0$ & - \\
0,04 & $8-0$ & $8-0$ \\
0,05 & $7-0$ & $7-0$ \\
0,07 & $6-0$ & $6-0$ \\
0,1 & $5-0$ & $5-0$ \\
0,15 & $4-0$ & $4-0$ \\
0,2 & $3-0$ & $3-0$ \\
0,3 & $2-0$ & $2-0$ \\
0,35 & 0 & 0 \\
0,4 & 1 & 1 \\
0,5 & 2 & 2 \\
0,6 & 3,4 & 3 \\
0,7 & 5 & 4 \\
0,8 & 6 & - \\
0,9 & 7 & \\
\hline
\end{tabular}

USP = United States Pharmacopeia.

\section{Considerações acerca da cicatrização}

O cirurgião deve considerar como a sutura altera os processos biológicos no ambiente do ferimento em cicatrização. $\mathrm{O}$ tecido responde às suturas como responderia a outro material estranho. A intensidade da reação depende da natureza da sutura implantada, da quantidade ou área de superfície da sutura, do tipo e da localização do tecido fechado com suturas (as vísceras intestinais e a pele reagem fortemente à seda e às fáscias reagem minimamente á seda), 
do comprimento da implantação e finalmente, da técnica de colocação da sutura (o aperto excessivo da sutura causa o estrangulamento do tecido). A reação tecidual excessiva induzida por sutura aumenta a probabilidade de um rompimento da sutura por amolecimento dos tecidos circundantes e isso retarda o início da fibroplasia. As suturas que causam reação tecidual excessiva são contra-indicadas em áreas onde a formação de uma cicatriz exuberante possa causar um problema funcional (por exemplo, no caso de reparo vascular ou anastomose ureteral). $\mathrm{O}$ cirurgião deve se esforçar para infligir a menor quantidade de traumatismo necessária para a operação, minimizar a contaminação e utilizar suturas que causem a menor reação tecidual para evitar uma inflamação excessiva e uma cicatrização retardada do ferimento.

Todos os materiais de sutura são capazes de aumentar a suscetibilidade do ferimento a uma infecção. A natureza filamentosa da sutura, a capilaridade, a estrutura química, a bioinércia e a capacidade de aderência de bactérias exercem papéis em uma infecção relacionada a sutura.

A infecção do ferimento também afeta a integridade da sutura. Caso se suspeite de contaminação de ferimento, devem-se escolher suturas absorvíveis sintéticas, pois ficam mais estáveis no tecido contaminado. Caso se exija do material de sutura uma sustentação a longo prazo do ferimento, indica-se uma sutura absorvível (degradação prolongada) sintética ou nãoabsorvível monofilamentar sintética, tal como a polidioxanona ou o poligliconato.

A presença de qualquer material de sutura no interior da luz do trato biliar ou urinário pode induzir à formação de cálculo. Consequentemente, as suturas absorvíveis são recomendadas nessas áreas. O material de seda e poliéster, devido aos seus efeitos calculogênicos documentados, não deve permanecer em contato com urina ou bile.

Tabela 3. Tamanho da sutura e recomendações de uso gerais na cirurgia de pequenos animais.

\begin{tabular}{|c|c|c|}
\hline Tecido & Tamanho do fio de sutura & Materiais de sutura - Classe \\
\hline Pele & $3-0$ a $4-0$ & Não-absorvível monofilamentar \\
\hline Tecido subcutâneo & $2-0$ a $4-0$ & Absorvível \\
\hline Fáscia & 1 a $3-0$ & $\begin{array}{l}\text { Absorvível sintético (degradação prolongada) ou } \\
\text { não-absorvível sintético }\end{array}$ \\
\hline Músculo & 0 a $3-0$ & $\begin{array}{l}\text { Esquelético - absorvível ou não-absorvível } \\
\text { sintéticos } \\
\text { Cardíaco - não-absorvível sintético }\end{array}$ \\
\hline Órgão parenquimatoso & $2-0$ a $4-0$ & Absorvível \\
\hline Órgão visceral oco & $2-0$ a $5-0$ & Absorvível ou não-absorvível monofilamentar \\
\hline Tendão, ligamento & 0 a $3-0$ & $\begin{array}{l}\text { Não-absorvível monofilamentar, absorvível } \\
\text { sintético (degradação prolongada) }\end{array}$ \\
\hline Nervo & $5-0$ a $7-0$ & Não-absorvível monofilamentar \\
\hline Córnea & $8-0$ a $10-0$ & $\begin{array}{l}\text { Absorvível sintético, não-absorvível não- } \\
\text { metálico }\end{array}$ \\
\hline Ligadura vascular & $3-0$ a $4-0$ & Absorvível \\
\hline Reparo vascular & $5-0$ a $7-0$ & Não absorvível monofilamentar \\
\hline
\end{tabular}

Fonte: FOSSUM 2005.

\section{Propriedades mecânicas da sutura e do tecido}

As propriedades ou funções mecânicas da sutura devem ser semelhantes às do tecido a ser fechado. $\mathrm{O}$ náilon, $\mathrm{o}$ polipropileno $\mathrm{e}$ provavelmente o polibutéster devem ser os mais adequados para pele, devido à sua capacidade de alongamento. Os materiais de sutura inelásticos (tais como os materiais de sutura de poliéster) são mais aplicáveis para procedimentos protéticos ou sobreposição de articulações.

O cirurgião deve considerar esses princípios de sutura gerais e escolher a melhor sutura, com 
base em suas características físicas e químicas, para as exigências específicas dos tecidos a serem fechados. As características físicas incluem a durabilidade, a qualidade de manipulação, a segurança do nó e o dano por esterilização com calor. As características biológicas incluem o modo de absorção, a reatividade tecidual, a predisposição a infecção, a formação de cavidade e o potencial calculogênico.

A escolha final da sutura deve basear-se na preferência pessoal somente após ter-se compreendido completamente as características do material de sutura, a interação entre a sutura e o tecido e os processos biológicos na cicatrização do ferimento. Torna-se óbvio que a escolha do material de sutura para o fechamento do ferimento possa determinar o sucesso ou o fracasso de um procedimento cirúrgico. A técnica de colocação de sutura e de manipulação do tecido, no entanto, permanece até mais importante que a seleção da sutura para uma cicatrização de ferimento não-complicada.

\section{AGULHAS CIRÚRGICAS}

Várias formas e tamanhos de agulhas encontram-se disponíveis; a escolha depende do tipo de tecido a ser suturado (por exemplo, penetrabilidade, densidade, elasticidade $\mathrm{e}$ espessura), da topografia do ferimento (por exemplo, profunda ou rasa) e das características da agulha (por exemplo, tipo de olho, comprimento e diâmetro).

Os três componentes básicos de uma agulha são extremidade de acoplamento (ou seja, moldada ou com olho), corpo e ponta (Figura 17, A). As agulhas com olho devem ter o fio enfiado e, pelo fato de um fio de sutura duplo ser puxado através do tecido, cria-se um orifício maior do que quando se usa material de sutura moldado. As agulhas podem ser fechadas (ou seja, redondas, retangulares ou quadradas) ou francesas (ou seja, com uma fenda desde o lado interno do olho até a extremidade para facilitar a passagem do fio) (Figura 17, B). As agulhas com olho devem ter fios enfiados a partir da curvatura interna. No caso de fios de sutura moldados, a agulha e o fio de sutura constituem uma unidade contínua, o que minimiza o traumatismo tecidual e aumenta a facilidade de uso.

O corpo da agulha vem em várias formas (Figura 17, C); o tipo de tecido e a profundidade e o tamanho do ferimento determinam a forma apropriada. As agulhas retas (de Keith) são usadas geralmente em locais acessíveis, nos quais a agulha pode ser manipulada diretamente com os dedos (por exemplo, colocação de suturas em bolsa no ânus). As agulhas curvas devem ser manipuladas com porta-agulhas. A profundidade e o diâmetro de um ferimento são importantes quando se escolhe a agulha curva mais adequada. As agulhas de um quarto (1/4) de círculo são usadas primariamente em procedimentos oftalmológicos. As de três oitavos (3/8) e de meio (1/2) círculo são as agulhas cirúrgicas mais comumente usadas na medicina veterinária (por exemplo, para fechamento abdominal). As agulhas de 3/8 de círculo são manipuladas com maior facilidade do que as de meio círculo, pois exigem menos pronação e supinação do pulso. No entanto, por causa do maior arco de manipulação requerido, elas são desajeitadas para uso em posições profundas ou inacessíveis. Agulhas de meio círculo ou de cinco oitavos (5/8) de círculo, apesar de exigirem mais pronação e supinação do pulso, são mais fáceis de usar em posições confinadas.

A ponta (ou seja, de corte, afilada, de corte reverso ou de corte lateral) (Figura 17, D), afeta a afiação de uma agulha e o tipo de tecido em que se usa a mesma. As agulhas de corte apresentam geralmente duas ou três bordas de corte opostas. Elas são projetadas para uso em tecidos difíceis de penetrar (tais como a pele). No caso das agulhas de corte convencionais, a terceira borda de corte encontra-se na curvatura interna (ou seja, côncava) da agulha. Essa localização da borda de corte interna pode promover um "recorte" do tecido, pois ela corta na direção das bordas do ferimento ou da incisão.As agulhas de corte reverso possuem uma terceira borda de corte localizada na curvatura externa (ou seja, convexa); isso as torna mais fortes que as agulhas de corte convencionais de tamanho semelhante e reduz o risco de recorte tecidual. As agulhas de corte lateral (ou seja, agulhas em espátula) são chatas nas partes superior e inferior. Geralmente são usadas em procedimentos oftalmológicos. As agulhas afiladas (ou seja, agulhas redondas) possuem uma ponta afiada que perfura e abre tecidos sem cortá-los. Elas são usadas geralmente em tecidos facilmente penetráveis, tais como intestino, tecido subcutâneo ou fáscias. As agulhas de corte afilado, que são uma combinação de ponta de borda de corte reverso e corpo de ponta afilada, geralmente são usadas para suturar tecidos fibrosos, densos e resistentes (tais como tendões) e no caso de alguns 
procedimentos cardiovasculares (tais como enxertos vasculares). As agulhas de ponta romba e arredondada podem dissecar tecidos friáveis sem cortá-los. Ocasionalmente são usadas para suturar órgãos parenquimatosos moles (tais como fígado e rins).
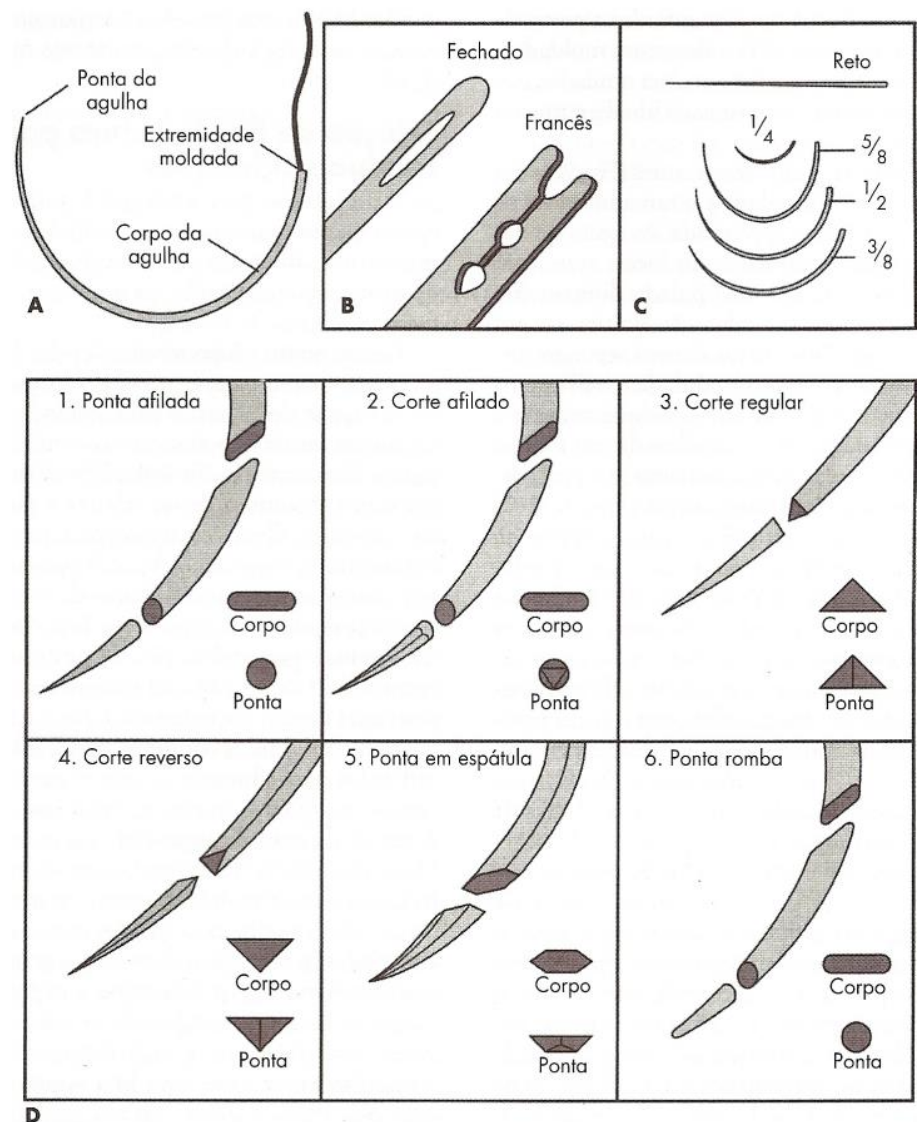

Figura 17. A. Componentes básicos de uma agulha. B. Tipos de agulha com olho. C. e D. Formas e tamanhos de corpos das agulhas.

\section{SELEÇÃO DE FIO DE SUTURA PARA TIPOS TECIDUAIS DIFERENTES}

As considerações para a seleção de um fio de sutura incluem quanto tempo ele terá de ajudar a reforçar o ferimento ou tecido, o risco de infecção, o efeito do material de sutura na cicatrização do ferimento e a dimensão e força necessária da sutura, assim como foi abordado anteriormente.

\section{Fechamento abdominal}

$\mathrm{Na}$ pele, devem ser usados fios monofilamentares para evitar trançamento ou transporte capilar de bactérias para tecidos mais profundos. Os fios de sutura não-absorvíveis monofilamentares sintéticos possuem boa segurança de nó relativa e são relativamente nãocapilares. Fios de sutura absorvíveis podem ser empregados na pele, mas devem ser removidos, pois a absorção requer contato com fluidos corporais. Suturas subcutâneas são utilizadas para obliterar o espaço morto e diminuir a tensão nas bordas cutâneas; para isso, prefere-se um material de sutura absorvível. A fáscia do músculo reto abdominal pode ser fechada com um padrão de sutura interrompido ou contínuo. Quando se adota um padrão de sutura contínuo, deve-se utilizar um fio de sutura monofilamentar forte com boa segurança de nó. No caso de um padrão de sutura contínuo, prefere-se um fio de sutura de tamanho maior do que seria usado normalmente. Os nós devem ser amarrados cuidadosamente.

\section{Músculos e tendões}

Os músculos têm fraco poder de retenção e são difíceis de suturar. Podem ser usados materiais de sutura absorvíveis ou nãoabsorvíveis. Suturas colocadas paralelamente às fibras musculares têm probabilidade de sair do local. O material empregado para um reparo tendinoso deve ser forte, não-absorvível e minimamente reativo. Uma sutura com agulha afilada ou de corte-afilada é geralmente menos 
traumática. Deve-se usar o maior fio de sutura que passe com mínimo traumatismo através do tendão.

\section{Órgãos parenquimatosos e vasos}

Órgãos parenquimatosos (tais como fígado, baço e rins) geralmente são suturados com fios monofilamentares absorvíveis. Devem ser evitados fios multifilamentares em áreas de contaminação, e fios de sutura com arrasto maior podem tender a cortar os tecidos.

\section{Órgãos viscerais ocos}

Recomendam-se geralmente fios de sutura absorvíveis para órgãos viscerais ocos (tais como traquéia, trato gastrintestinal ou bexiga) para evitar retenção tecidual de material estranho quando o ferimento cicatrizar. Além disso, um fio de sutura não-absorvível pode se tornar calculogênico quando colocado na bexiga ou na vesícula biliar.

\section{Ferimentos infectados ou contaminados}

Se possível, devem ser evitados fios de sutura em ferimentos altamente contaminados ou infectados. Não devem ser usados fios de sutura não-absorvíveis multifilamentares em tecidos infectados, pois eles potencializam a infecção e podem fistular. Prefere-se um material absorvível; no entanto, deve-se evitar o categute cirúrgico, pois sua absorção em tecido infectado é imprevisível. Os fios de sutura monofilamentares sintéticos de náilon e polipropileno (não-absorvíveis) podem deflagrar menos infecção em tecidos contaminados do que fios metálicos.

\section{PRINCÍPIOS CIRÚRGICOS GERAIS}

O sucesso de uma operação cirúrgica depende não só da compreensão dos princípios básicos de divisão de tecidos, hemostasia e fechamento da ferida, como também de um centro cirúrgico bem equipado, mantido por equipe treinada, que tem uma rotina organizada e estabelecida para esterilização de instrumentos e para preparo e assistência às operações.

Nenhum centro cirúrgico fornece todas as exigências ideais, mas isto não é desculpa para não se procurar os padrões de assepsia, os mais aceitáveis possíveis, dentro das instalações do centro e do equipamento disponível.

São vários os tipos de operação além daquelas realizadas em tecidos normalmente nãoinfectados, como ovariohisterectomia de rotina e a maioria dos processos ortopédicos; operações no aparelho gastrointestinal, durante as quais o conteúdo intestinal pode contaminar tanto os instrumentos como as mãos do cirurgião; e finalmente exploração de tecido excessivamente infectado, como fístulas.

Os casos potencialmente infectados devem sempre ser deixados para o fim de uma série de cirurgias e deve-se tomar um cuidado especial para evitar a transferência da infecção para os instrumentos, panos de campo e acessórios. Para este fim, é prática normal em operações que envolvem a abertura de porções do aparelho gastrointestinal fazer uso de uma toalha suplementar adicional, de cor distinta. Nesta toalha são colocados todos os instrumentos usados para abrir e fechar o intestino e postos de lado como potencialmente contaminados, antes de se realizar o fechamento da cavidade abdominal.

Deve ser regulamento preestabelecido que nenhuma pessoa terá permissão para entrar no centro cirúrgico sem primeiro vestir a indumentária protetora apropriada, que deve incluir sapatilhas, gorro, máscara e avental.

\section{ROTINA NO CENTRO CIRÚRGICO}

\section{Preparação dos carrinhos de instrumentos}

Se os carrinhos são preparados para uma série de operações é impossível garantir sua esterilização mesmo se forem cuidadosamente cobertos, portanto, os carrinhos de instrumentos devem ser preparados antes de cada operação da seguinte forma:

1. A superfície do carrinho deve ser limpa com solução desinfetante.

2. O carrinho é coberto com um pano esterilizado (pano de mesa).

3. A bandeja de instrumentos (estéril) é então colocada no carrinho de instrumentos.

\section{Preparo da equipe cirúrgica}

Depois de preparado o carrinho de instrumentos, o instrumentador ou auxiliar prepara-se para dar assistência à operação, assim 
como o cirurgião. Isto envolve limpeza das mãos e antebraços com escova, colocação do avental esterilizado e luva. A seguir são descritas as sequências de procedimentos durante o preparo da equipe cirúrgica:

\section{$\underline{\text { 1. Colocação de roupas secundárias }}$}

As roupas secundárias são usadas na área de cirurgia para limitar a quantidade de sujeira, resíduos e bactérias que a equipe cirúrgica leva para dentro da área cirúrgica. As roupas secundárias são feitas de um tecido de textura frouxa, destinado mais ao conforto que a funcionar como uma barreira para microrganismos.

\section{Colocação de cobertura para a cabeça (gorro)}

As coberturas para a cabeça (gorro) são empregadas para reduzir a queda de cabelos e bactérias na incisão. Todas as pessoas na sala de cirurgia usam coberturas para a cabeça, que precisam ser duráveis e confortáveis. Os gorros devem cobrir todo o cabelo na cabeça.

\section{Colocação de máscaras}

As máscaras são recomendadas para qualquer um que entre na sala cirúrgica durante a cirurgia. As máscaras cobrem o nariz e a boca, e são amarradas atrás da parte superior da cabeça e do pescoço, para que haja mínima saída de ar. Sua principal função é proteger a ferida cirúrgica de gotículas de saliva e microrganismos, direcionando o fluxo de ar para fora das laterais da máscara, longe da incisão. Não é preciso usar uma máscara na sala de cirurgia se os pacotes de instrumentos não estiverem abertos ou se não estiver sendo realizada uma cirurgia

\section{Colocação de cobertura para sapatos (propés)}

As coberturas para sapatos (propés) são usadas para reduzir bactérias presentes em sapatos de rua, para reduzir a possibilidade de contaminação da sala de cirurgia e proteger os sapatos de contaminação por sangue e bactérias hospitalares.

\section{Limpeza com escova}

Deve-se tomar cuidado ao esfregar mãos e antebraços para assegurar que estejam cuidadosamente limpos, e atenção especial deve ser dada às unhas e entre os dedos.

a) Abrir a torneira de modo a obter um fluxo de água satisfatório. b) Os antebraços e mãos são esfregados com uma escova, com atenção especial às unhas e entre os dedos. A esfregadura não deve consumir tempo nem irritar a pele (se utilizadas com força excessiva, podem lesar a pele, levando à multiplicação de bactérias cutâneas e a maior eliminação no ambiente). As unhas devem ser mantidas curtas, limpas e sem esmalte. Todas as superfícies das mãos e antebraços são expostas à esfregadura antiséptica por no mínimo dois minutos. Recomenda-se que a primeira esfregadura do dia seja de 5 minutos, e as esfregaduras seguintes de 2 a 5 minutos.

c) As mãos são mantidas acima do cotovelo, assegurando que o fluxo de água escorra das pontas dos dedos para o cotovelo.

d) Utilizar os cotovelos para fechar a torneira.

e) Utilizar toalhas esterilizadas para secar a mão e o antebraço. Segure a toalha e, empregando movimento de mata-borrão, seque uma mão e um braço, procedendo da mão ao cotovelo, com uma face da toalha. Com a mão e o braço secos, leve a mão seca ao lado oposto da toalha. Seque a outra mão e o outro braço de modo semelhante.

\section{$\underline{\text { 6. Colocação do avental esterilizado }}$}

Como é impossível manter as mãos completamente esterilizadas lavando e esfregando, elas não devem entrar em contato com nenhuma parte fora do avental. Os aventais são embalados individualmente e dobrados de modo que o seu lado interno fique para fora, permitindo que esta área seja manipulada sem contaminar a superfície externa do avental.

a) Para ser vestido, o avental é segurado como uma unidade completa.

b) A pessoa que põe o avental entra em uma área limpa, segurando o avental pela superfície interna da região do pescoço. O resto do avental é, então, desdobrado em direção ao chão. O avental é aberto, de tal modo que sua superfície interna fique voltada para frente do cirurgião.

c) Os braços são introduzidos nas mangas e depois suspensos para permitir que o avental caia na posição.

d) O assistente ajusta o avental por trás e amarra as tiras. Uma vez colocado, apenas a frente do avental, da região inferior do ombro ao 
nível da mesa e as mangas, são partes consideradas estéreis.

\section{Colocação das luvas esterilizadas}

As luvas são usadas pela equipe cirúrgica para proteger o paciente dos microrganismos na pele das mãos da equipe. Protegem também a equipe dos microrganismos do paciente. $\mathrm{O}$ método para calçar as luvas esterilizadas garante que, em tempo algum, a mão entre em contato com o lado de fora das luvas. Os pacotes de luvas são estéreis, a menos que a embalagem esteja danificada. Abre-se a embalagem e retira-se um envelope de papel contendo as luvas, que são colocadas num campo estéril. O envelope é aberto e segue-se então com a técnica para a colocação das luvas.

a) A luva da mão direita é apanhada com a mão esquerda segurando apenas a parte interna do punho (a luva tem o punho dobrado), e a mão direita é inserida.

b) Pega-se a luva da mão esquerda com a mão direita enluvada, segurando-se de tal maneira que ela só tenha contato com a parte externa da luva. A mão esquerda é inserida.

c) Vira-se para trás o punho de ambas as luvas, fazendo os ajustes necessários.

\section{Preparo para a cirurgia}

\section{Colocação de panos de campo no paciente}

As etapas básicas da preparação do local cirúrgico são remoção dos pêlos, limpeza e antisepsia da área ( $1^{\mathrm{a}}$ anti-sepsia), transporte do paciente para a sala cirúrgica, posicionamento do paciente e aplicação de panos de campo assépticos ao campo cirúrgico.

Os panos de campo isolam o local cirúrgico de áreas contaminadas e proporcionam uma área de trabalho estéril. Eles isolam uma área central contendo o local da incisão proposta, sendo presos à pele do paciente por pinças de campo. Depois de colocados os panos de campo é feita a $2^{\mathrm{a}}$ anti-sepsia somente no local em que será feita a cirurgia, sendo esta realizada pelo auxiliar ou pelo cirurgião.

Em casos de cirurgia na região abdominal, onde há exposição de órgão e vísceras, normalmente são usados panos de campo adicionais ( $2^{\circ}$ pano de campo) que são colocados nas bordas da incisão. São usados para prevenir a contaminação acidental da incisão, pois nesses procedimentos os perigos de contaminação são maiores

2. Distribuição do material cirúrgico sobre a $\underline{\text { mesa }}$

Tendo o auxiliar ou instrumentador preparado o carrinho de instrumentos, colocado o avental esterilizado e calçado as luvas, deve agora arrumar os instrumentos. Estes devem ser dispostos após ter sido colocado o pano de mesa e de maneira que o instrumentador possa dar assistência ao cirurgião durante toda a cirurgia. Não se deve abrir a mesa de instrumentos até que o animal esteja posicionado na mesa cirúrgica e preparado com panos de campo estéreis. Após o kit de instrumentos ter sido aberto, esses devem ser posicionados de maneira que possam ser pegos facilmente (figura 18).

\begin{tabular}{|c|c|l|}
\hline $\begin{array}{c}\text { Materiais especiais (pinças } \\
\text { teciduais) } \\
\text { E }\end{array}$ & $\begin{array}{c}\text { Síntese (agulhas, fios e porta } \\
\text { agulhas) } \\
\text { S }\end{array}$ & $\begin{array}{c}\text { Instrumental auxiliar (pinças de } \\
\text { dedo) } \\
\text { A }\end{array}$ \\
\hline $\begin{array}{c}\text { Pinças de campo } \\
\text { C }\end{array}$ & $\begin{array}{c}\text { Pinças hemostáticas } \\
\text { H }\end{array}$ & $\begin{array}{l}\text { Material de diérese (bisturi e } \\
\text { tesouras) }\end{array}$ \\
\hline
\end{tabular}

Figura 18. Distribuição do material cirúrgico sobre a mesa.

Obs.: Inicialmente o espaço C ficará vazio, logo, o assepsista dará as compressas para o instrumentador colocá-las no espaço $\mathbf{C}$ 


\section{INCISÕES CIRÚRGICAS DA PAREDE DO ABDOME}

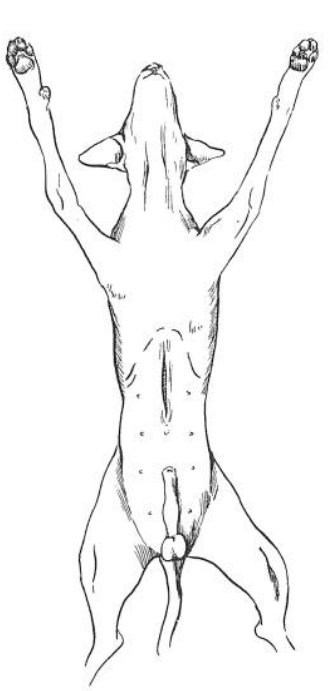

Figura 19. Incisão pré-umbilical: se estende desde a cartilagem xifóide no osso esterno até a cicatriz umbilical, na linha mediana (linha alba). Esta via dá acesso ao diafragma, fígado, baço, estômago e piloro.

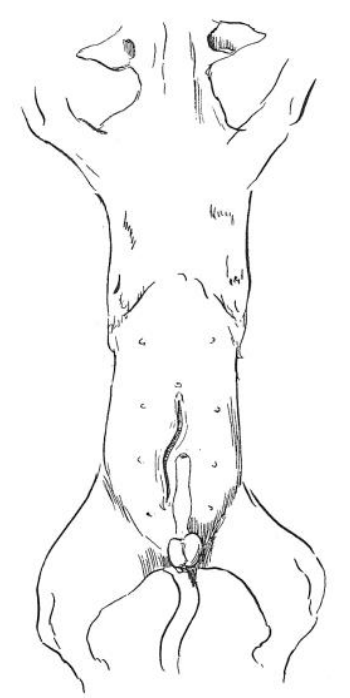

Figura 20. Incisão retro-umbilical no macho: se estende abaixo (caudal) à cicatriz umbilical na linha mediana. Essa via dá acesso a bexiga, próstata, intestinos e abdome inferior.

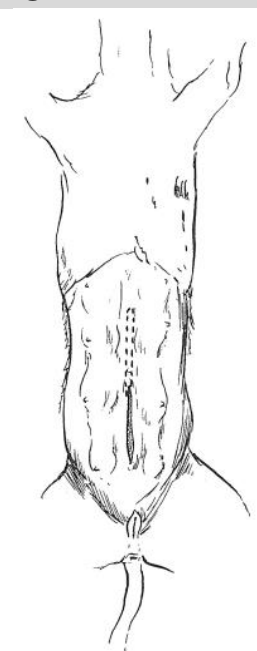

Figura 21. Incisão retro-umbilical na fêmea: se estende desde a cicatriz umbilical até a altura da borda da pelve. Este método permite o acesso cirúrgico aos ovários, útero, intestinos, bexiga e abdome inferior. A linha pontilhada indica uma extensão da incisão feita, a qual trata-se da incisão pré-retro-umbilical, que passa pela cicatriz umbilical. Esta via é utilizada quando necessita de uma exposição maior, em casos de cesariana e exposição do rim direito.

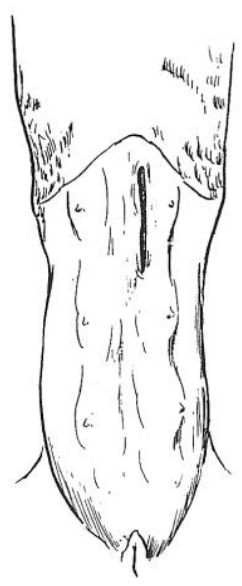

Figura 22. Incisão paramediana: é realizada lateralmente a linha mediana, lateral a linha alba.

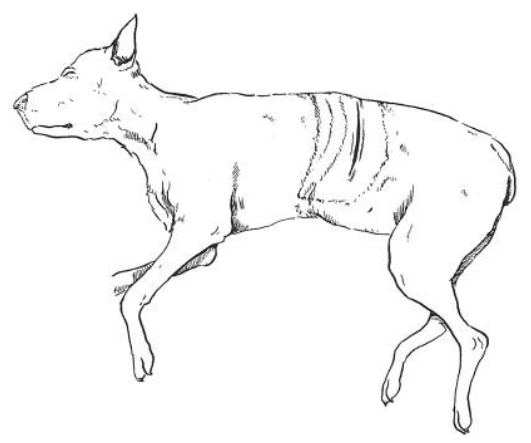


Figura 23. Incisão paracostal: é feita atrás da última costela. Esta via dá acesso ao rim, baço e discos intervertebrais da região lombar.

\section{SUTURAS USADAS NA MEDICINA VETERINÁRIA}

Quando os tecidos são divididos, devem ser mantidos juntos até que se realize a cicatrização normal. Existem vários e elaborados métodos de sutura, também conhecida como síntese, mas não se deve esquecer que o propósito da sutura é manter os tecidos unidos na melhor posição para cicatrização e isto deve ser atingido pelos métodos mais simples e usando-se a quantidade mínima de material de sutura.

A ausência de indevida tensão é um prérequisito essencial à perfeição da sutura, e os pontos só devem ser firmemente puxados para trazer os bordos da ferida à perfeita justaposição e para controlar o sangramento. Se a tensão é excessiva, as suturas podem se romper ou originar áreas de tecido isquêmico, que contribuem para a degradação da ferida.

Cirurgiões destros devem realizar as suturas sempre da direita para a esquerda, enquanto cirurgiões canhotos devem fazer o oposto.

Ajudados por esquemas, vamos ver as principais suturas de interesse cirúrgico e suas indicações mais importantes. As adaptações são inúmeras e ao cirurgião fica o critério, a liberdade de aproveitar as características próprias de cada uma para o uso que lhe pareça melhor. Tendo em vista estas características, o cirurgião pode estabelecer preferência por um determinado tipo, havendo muito de pessoal nesta escolha, dependendo de: sua maneira própria de trabalhar, o tipo da ferida, a região, a espécie, a raça e temperamento, a idade, a condição física do paciente e outros, podem ser fatores que determinam a variação na escolha do tipo de sutura a empregar.

As suturas podem ser divididas, para maior facilidade de estudo em: contínuas, em pontos separados ou interrompida, e combinadas.

As suturas combinadas são aquelas constituídas pela conjugação de uma contínua com uma em pontos separados, de duas contínuas ou de duas em pontos separados.

A aplicação de pontos separados para reforçar uma contínua, é um exemplo de combinada, na qual buscamos tirar de cada uma sua melhor característica, com a finalidade de obter melhor resultado. O grave inconveniente das suturas contínuas, é que se chegam a romper em um ponto, toda a sutura estará perdida, o que nos leva a fazer combinações, sempre que os riscos forem maiores. As combinações podem ser as mais variadas e o cirurgião, conhecendo as suturas contínuas e separadas, poderá combiná-las segundo a conveniência de cada caso.

As suturas também podem ser chamadas de perdidas ou internas, quando ficam situadas internamente, aplicadas em órgãos e músculos, e chamadas de externas quando aplicadas externamente, como no caso das suturas de pele.

\section{TIPOS DE SUTURAS}

Os padrões de sutura podem ser classificados de acordo com os seguintes fatores:

1. Áreas anatômicas em que são colocadas (tecidos que aproximam);

2. Pela maneira como aproximam os tecidos (por exemplo, de aproximação, eversores ou invertores), ou seja, tendência para promover aposição, inversão ou eversão dos tecidos. As suturas de aproximação (por exemplo, suturas interrompidas simples) aproximam bastante o tecido. As eversoras (por exemplo, sutura de colchoeiro) viram as bordas do tecido para fora da ferida. As suturas inversoras (por exemplo, sutura de Lembert, de Connell e de Cushing) são realizadas para inverter os bordos da ferida em direção ao lúmen de um órgão visceral oco, e é comumente usada em cirurgia gastrointestinal. A capacidade de um padrão de inverter ou revirar tecidos pode ou não ser benéfica, dependendo da área anatômica. Embora seja frequentemente desejável para o fechamento de vísceras ocas, a inversão é considerada prejudicial para a cicatrização adequada da pele.

3. Capacidade para superar as forças de tensão que podem romper a aproximação precisa dos tecidos; 
4. Se são colocadas de modo contínuo ou em pontos separados (interrompidos). Assim temos os seguintes tipos de sutura:

- Suturas contínuas.

- Suturas em pontos separados.

- Suturas combinadas.

\section{Suturas em pontos separados}

Suturas interrompidas ou em pontos separados são aquelas realizadas com pontos isolados, onde o fio da sutura é interrompido. É a sutura mais comum de uso geral. Uma agulha, junto com o material de sutura, é inserida através dos bordos do tecido. Esta única laçada de sutura é então atada. A distância que a agulha é inserida do bordo do tecido e a distância entre as suturas é questão de preferência pessoal, mas deve estar relacionada com o tamanho da ferida e com a tensão dos tecidos, não devendo ser menor que a espessura do tecido a ser suturado.

As vantagens das suturas interrompidas são: manter a aposição dos tecidos se um ponto se romper (cada sutura é uma entidade separada nos padrões de pontos interrompidos, e muitas vezes a falha de um ponto é inconseqüente); cada ponto tem um nó individual, ou seja, cada ponto é uma unidade independente e não se sujeita a pressão dos pontos adjacentes. Desta forma, a maior vantagem dos tipos de suturas em pontos separados é a capacidade de ajustar precisamente a tensão em cada ponto ao longo da ferida, de acordo com forças expansoras variáveis ao longo de suas margens.

As desvantagens dos pontos separados incluem maior tempo necessário para a execução de múltiplos nós, maior volume de material estranho deixado na ferida e pouca economia de fios de sutura.

De modo geral, as suturas em pontos separados oferecem muito mais segurança, porém de execução mais demorada. Seu emprego é quase que só em suturas externas, já aplicadas internamente oferecem o inconveniente de muitos nós e pontas de fios, o que é indesejável. Tem a grande vantagem, em permitir a retirada de um ou dois pontos sem comprometer a estrutura, facilitando drenagens.

1. Sutura em pontos simples separados ou simples interrompidos

Sutura simples interrompida é o modelo de sutura mais antigo e mais amplamente utilizado, por oferecer uma boa cicatrização, pela simplicidade de execução, segurança, além de ser relativamente rápida de realizar. Uma sutura interrompida simples é feita pela inserção da agulha e do fio através do tecido, de um lado da incisão ou ferimento, cruzando a ferida em ângulo reto, e são inseridos através do tecido no lado oposto, amarrando-se então o fio. Assim, a penetração da agulha ocorre a uns poucos milímetros da borda da ferida, em sentido transversal a esta, para sair na borda oposta, a uma mesma distância da entrada (Figura 24).

O nó deve estar excêntrico de modo que não repouse contra a incisão (o nó deve ser dado em um dos lados da ferida e nunca sobre a linha da incisão), e as extremidades do fio devem ser cortadas (no caso de suturas cutâneas, as extremidades devem ser deixadas suficientemente longas para serem pegas durante a remoção). Se a sutura for utilizada para o fechamento de pele, o ponto de inserção da agulha em relação à borda da ferida irá variar, dependendo da espessura da pele. Este pode ser um centímetro na pele bovina ou de até dois a três milímetros para a pele delgada da região inguinal de um potro. E o tipo de sutura mais indicado para ser utilizado na pele.

A sutura interrompida simples deve aproximar as margens do ferimento, mas estas podem ficar invertidas se forem puxadas muito fortemente. Uma inversão cutânea causa cicatrização deficiente, portanto, deve-se ter cuidado para assegurar que as suturas cutâneas fiquem frouxas $\mathrm{e}$ as bordas, aproximadas. $\mathrm{O}$ espaçamento entre as suturas dependerá da tensão nas bordas do ferimento. Naturalmente devem ser evitadas lacunas nas bordas do ferimento.

\section{$\underline{\text { 2. Sutura de relaxamento }}$}

Esta sutura é praticada de maneira idêntica à anterior. A diferença está em que, após aplicados dois ou três pontos, aplica-se um, cuja penetração e saída se dão mais longe da borda da ferida que os demais (Figura 25). Tem a vantagem de permitir maior expansão dos tecidos, quando os edemas são problemas, sem o perigo de que o fio corte o tecido, que determina o rompimento dos pontos, daí o nome relaxamento.

Sutura de relaxamento é uma combinação de suturas de aposição com sutura de tensão. Sua principal indicação é quando a pele requer tensão moderada para aposição. O componente longe atua como redutor de tensão, ao passo que o perto 
faz a aposição. A tração excessiva dos fios deve ser evitada, para prevenir a inversão da incisão.

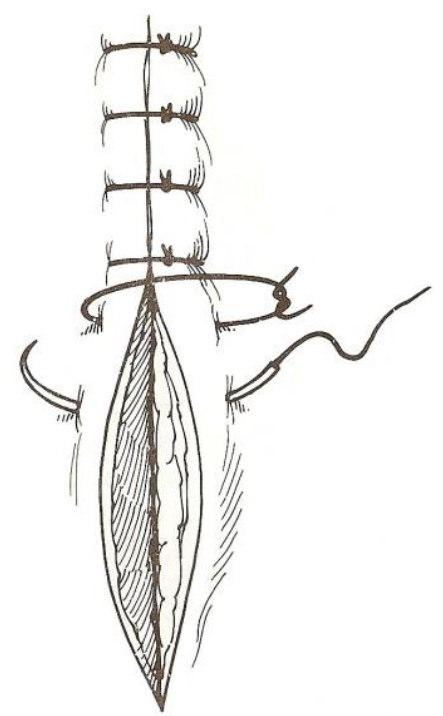

Figura 24. Sutura em ponto simples separado.

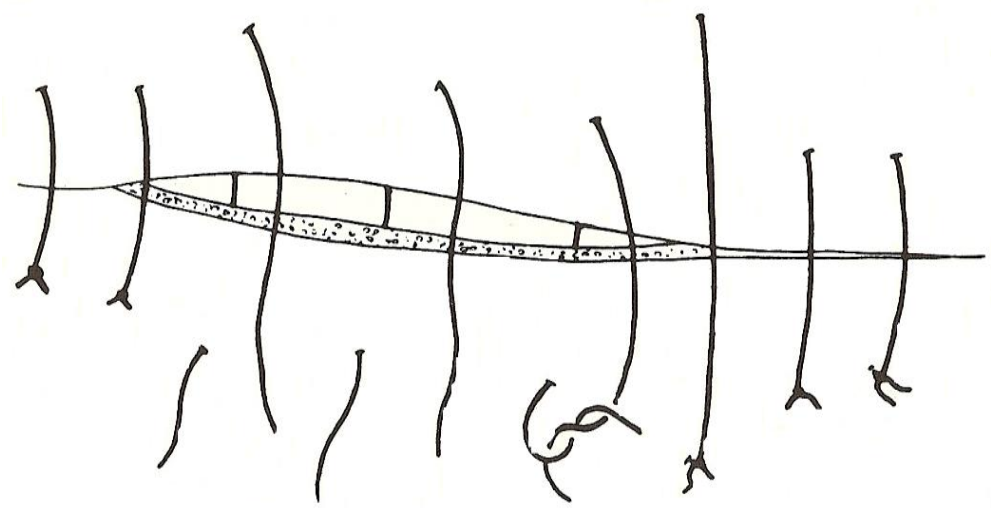

Figura 25. Sutura de relaxamento.

\section{Sutura horizontal de colchoeiro ou sutura} de Wolff

Sutura horizontal de colchoeiro interrompida também é conhecida como sutura horizontal em "U" (ou sutura em "U" deitado), ou ainda sutura de Wolff. São usadas primariamente em áreas de tensão e podem ser colocadas com rapidez, sendo útil para os ferimentos extensos de pele. No entanto, frequentemente, causam uma leve eversão tecidual, por isso deve-se ter cuidado para aproximar, em vez de everter, as margens teciduais. O fio de sutura deve ser angulado através do tecido de maneira que atravesse logo abaixo da derme. Nesta sutura as partes externas encontram-se paralelas às bordas do ferimento.

Ela é praticada mediante a introdução da agulha em um dos lados da incisão (lado distante) e dirigindo a mesma diretamente ao lado oposto (lado próximo), cruzando a ferida transversalmente, por baixo, saindo com a agulha a igual distância da borda, que a entrada anterior. Novamente introduzimos a agulha, na mesma borda de saída (lado próximo), um pouco ao lado - de uns dois milímetros, até um centímetro, dependendo do porte do animal e região sob intervenção - e percorremos um caminho oposto ao primeiro, saindo com a agulha do mesmo lado em que foi introduzida inicialmente (lado distante). As extremidades do fio se encontram e são a seguir atadas por nó completo (Figura 26). Uma das vantagens desta sutura, é que o fio não passa sobre a ferida, permitindo uma boa sustentação e é pois indicada sempre que exista maior tensão.

Devido à geometria da sutura horizontal de colchoeiro, as suturas têm uma tendência a reduzir o suprimento de sangue das bordas do 
ferimento. Em tal situação, a sutura vertical de colchoeiro seria uma melhor opção como sutura de tensão.

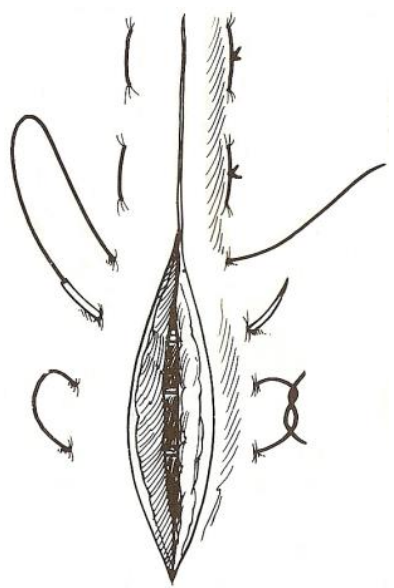

Figura 26. Sutura horizontal de colchoeiro interrompida.

\section{Sutura de Wolff com tubos de borracha ou} ponto de Wolff captonado

Praticada da mesma maneira que a anterior, com a diferença que se colocam pedaços de tubos de borracha ou botões, pelos quais o fio passa, naqueles pontos onde o fio emerge na pele (Figura 27). Nesta situação a sutura é colocada a alguma distância das bordas da pele. Outro modelo de sutura, como a sutura interrompida, pode ser usado para coaptar a linha de incisão. Esta sutura tem a grande vantagem de poder ser empregada em situações em que o fio fica sob forte tensão. Por sua presença, os tubos de borracha não permitem que o fio, sob tensão, penetre na pele, determinando a ruptura da mesma, ou seja, não permite tensão do fio diretamente sobre a pele.

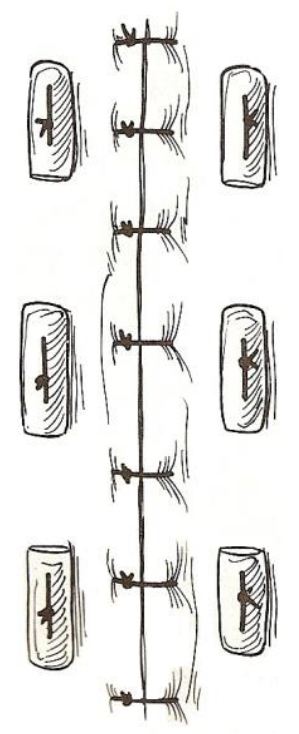

Figura 27. Sutura de Wolff captonada.

\section{Sutura vertical de colchoeiro ou sutura de}

\section{Donatti}

Têm as mesmas indicações, vantagens e possíveis desvantagens da de Wolff. Para realizála, a agulha é introduzida na pele a uns tantos milímetros da borda de incisão (aproximadamente $4 \mathrm{~mm}$ da borda de incisão em um lado), atravessa os tecidos e cruza a ferida em sentido transversal e vai emergir do lado oposto a igual distância da penetração. A agulha deve ser revertida e novamente inserida na pele no mesmo lado (de 8 a $10 \mathrm{~mm}$ da borda cutânea), para seguir um caminho igual ao anterior, um pouco mais abaixo deste, e retornar no lado oposto, saindo a igual distância da borda da última penetração, sendo a seguir dado o nó (Figura 28). 
Esta sutura é indicada para peles espessas como a dos bovinos. Tem a grande vantagem de dar cicatrizes de muito bom aspecto por promover excelente coaptação.

Sutura vertical de Colchoeiro ou de Donatti pode ajudar na eversão das extremidades de pele, promovendo uma aposição completa e precisa das bordas, com leve eversão após a confecção dos nós. Se esta sutura é usada como método exclusivo de fechamento da pele, a pega superficial da sutura assegurará uma boa aproximação das bordas do ferimento. Se for empregada como sutura aliviadora de tensão deve ser mantida a alguma distância do ferimento
Comparada ao modelo horizontal de colchoeiro, a geometria da sutura vertical permite uma melhor circulação nas bordas do ferimento, o que diminui as chances de necrose das margens. A única desvantagem desta sutura é que ela usa maior quantidade de material e pode tomar mais tempo.

As suturas de colchoeiro verticais são mais fortes que as horizontais, quando usados em áreas de tensão, além disso, a eversão de margens cutâneas é um problema menor neste tipo de sutura que nas suturas de colchoeiro horizontais.

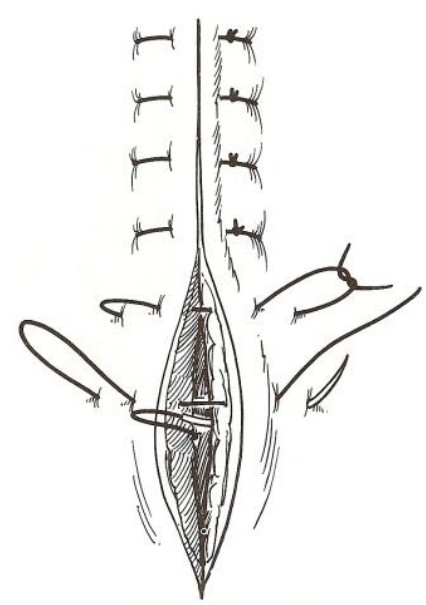

Figura 28. Sutura vertical de colchoeiro.

\section{Sutura vertical de colchoeiro como sutura de tensão}

Confecção idêntica à de Donatti, com a diferença de se interpor, entre o fio e a pele, os chamados captons, que são peças constituídas por um rolo de gaze, ou por tubos de borracha, sendo este tipo de sutura também chamado de sutura de Donatti captonada (Figura 29). Também pode ser usado um seguimento de madeira torneado (cavilha), sendo esta sutura conhecida como

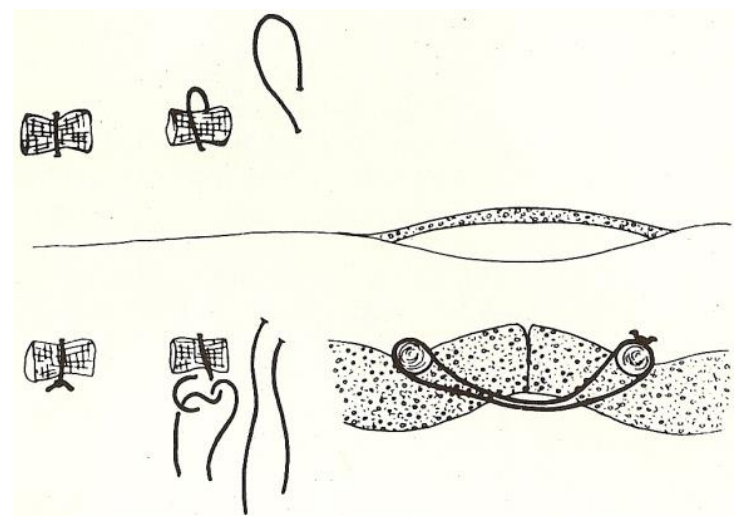

Figura 29. Sutura de Donatti captonada. sutura encavilhada (Figura 30). A cavilha pode ser constituída por um pedaço de madeira roliça, de comprimento pouco maior que a ferida, ou de um enrolado de gaze, com a mesma finalidade dos captons.

Tem as mesmas vantagens da sutura de Wolff com tubos de borracha, atuando como um dispositivo minimizando o corte de tecido pelo material de sutura.
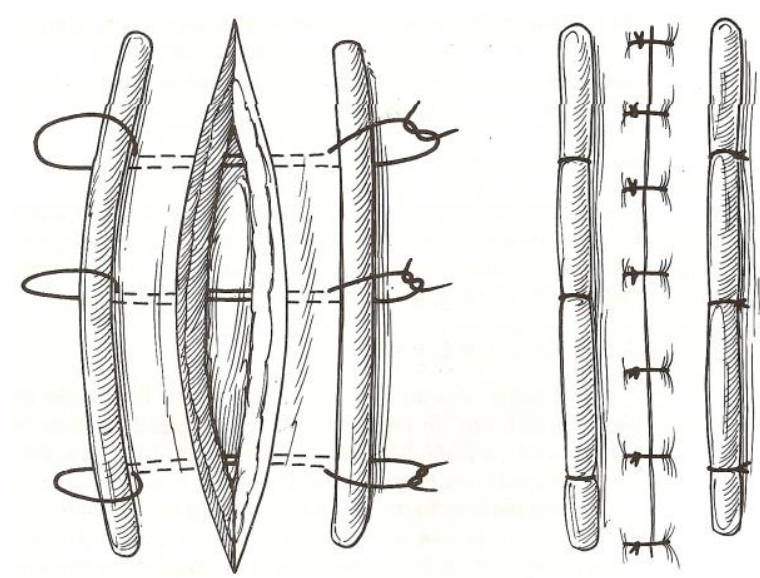

Figura 30. Sutura encavilhada. 


\section{Sutura de Lembert interrompida}

O padrão de Lembert trata-se de um padrão invaginante seromuscular utilizado frequentemente para fechar vísceras ocas. A agulha penetra a certa distância da borda da incisão, atingindo as camadas serosa, muscular e submucosa (mas não através da membrana mucosa), emergindo próximo à borda da incisão, no mesmo lado. Assim, a agulha deve penetrar da serosa até a camada submucosa, cerca de 8 a 10 $\mathrm{mm}$ da borda de incisão, e sair próximo da margem do ferimento, de 3 a $4 \mathrm{~mm}$ da borda, no mesmo lado. Depois de passar sobre a incisão (por cima), a agulha deve penetrar na borda oposta, a mesma distância da saída anterior (3 a 4 mm da borda da incisão), sendo novamente reintroduzida na serosa, muscular e submucosa, e sair de 8 a $10 \mathrm{~mm}$ de distancia da incisão. A parede da víscera será automaticamente virada conforme for dado o nó. O padrão deve ser repetido ao longo da extensão da incisão (Figura $31)$.

Em nenhum estágio a sutura deve penetrar o lúmen da víscera, sendo considerada um dos pontos de sutura mais seguros e úteis para a cirurgia gastrintestinal, podendo ser executada como um único plano de fechamento. Esta sutura também é conveniente para a aplicação no útero e rúmen. É uma sutura sero-muscular não contaminante.

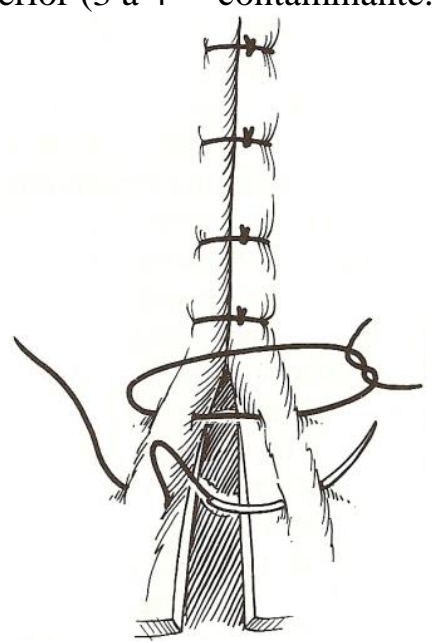

Figura 31. Sutura de Lembert interrompida.

\section{Sutura de Gely}

Sutura de Gely trata-se de uma inversão da sutura horizontal de colchoeiro interrompida. Nesta sutura, a perfuração é feita paralelamente a incisão passando pela camada muscular, e o material de sutura cruza externamente para o lado oposto da incisão. Desta forma, o fio de sutura passa perpendicularmente por fora da borda da ferida e novamente perfura paralelamente a incisão do lado oposto, sendo em seguida realizado o nó (Figura 32).

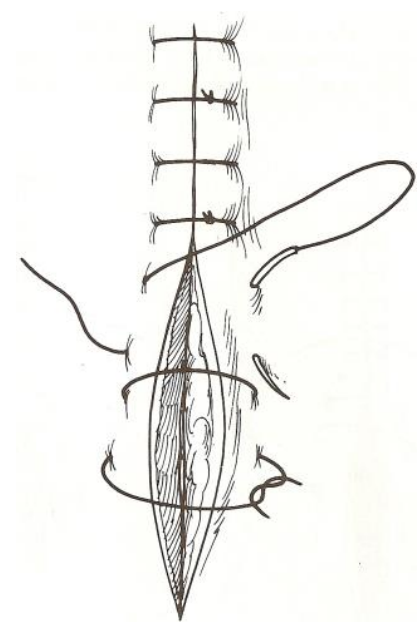

Figura 32. Sutura de Gely. 


\section{Sutura de Swift}

Especialmente indicada para suturar o esôfago, é assim praticada: a agulha é introduzida a partir da mucosa em direção à serosa, ou seja, de dentro para fora, penetra em seguida na borda oposta em sentido serosa mucosa, ou seja, de fora para dentro (ponto simples separado feito de maneira invertida, sendo a amarração do nó de sutura no interior da incisão). Assim as extremidades do fio de sutura ficam situados internamente, na luz do esôfago e o nó é aí praticado. Desta forma, pela menor irritação que esse tipo de ponto oferece, teremos diminuído as possibilidades de aderências, permitindo pois, maior mobilidade aos movimentos peristálticos do órgão (Figura 33).

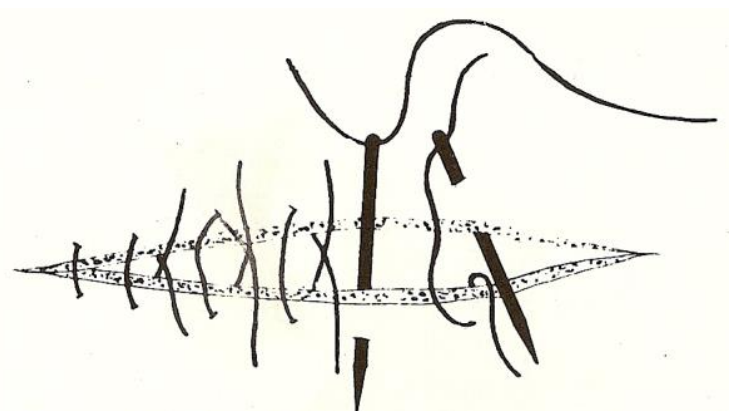

Figura 33. Sutura de Swift.

\section{Sutura em jaquetão}

Sutura que faz um transpasse de pele em cima de pele, promovendo uma maior aderência. Esta tem sua maior indicação no fechamento dos anéis herniários o que, entretanto, não a restringe a este uso, podendo ser aplicada em outros casos de acordo com a necessidade. Ela pode ser assim descrita: a agulha é introduzida de 2 a 4 centímetros da borda da ferida, penetrando de fora para dentro, atravessando toda a parede muscular; a seguir, a agulha passará pela abertura da ferida e será introduzida, no lado oposto, a 1 ou 2 centímetros da borda, também de fora para dentro. Em seguida a agulha é introduzida na massa muscular, de dentro para fora, de 2 a 4 centímetros além da ferida, do mesmo lado. A agulha é novamente introduzida, no lado oposto, também de dentro para fora, a 1 ou 2 centímetros da borda. Tracionadas as extremidades do fio, consegue-se o resultado apresentado no esquema da figura 34, dando aí o nó.
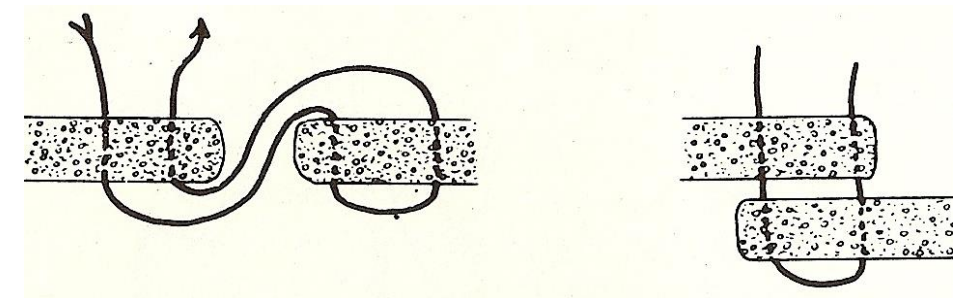

Figura 34. Sutura em jaquetão.

\section{Suturas com pontos em " $X$ " ou cruzada}

As suturas de colchoeiro horizontal podem ser modificadas para formar uma cruz sobre a incisão, passando a ser denominadas de suturas cruzadas ou em "X". Sutura com ponto em X ou cruzado é uma sutura de aposição, sendo uma modificação do "U" horizontal. Inicia-se introduzindo a agulha de um lado para o outro da incisão, como se fosse executar uma sutura interrompida. Então a agulha avança sem penetrar no tecido e, uma segunda passagem é feita paralela à primeira (no mesmo sentido da primeira). As extremidades da sutura estão então em lados opostos do ferimento formando um " $\mathrm{X}$ " em sua superfície (Figura 35).

A sutura com pontos em "X" é empregada por alguns cirurgiões como técnica de fechamento de pele e musculatura. Pode ser também empregada para reforçar suturas contínuas. 


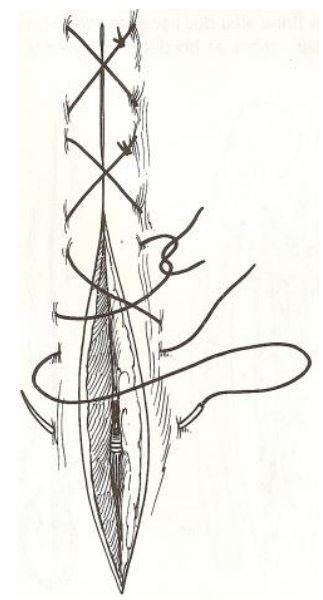

Figura 35. Sutura em ponto $X$.

\section{Sutura de Gambee}

As suturas de Gambee são usadas em cirurgias intestinais para reduzir a eversão de mucosa. O fio de sutura deve ser introduzido como em uma sutura interrompida simples da serosa, através da camada muscular e da mucosa, até o lúmen (Figura 36). Depois, deve-se retornálo do lúmen, do mesmo lado, através da mucosa, até a camada muscular, antes que cruze a incisão. Depois de cruzar a incisão, deve-se introduzi-lo na camada muscular, do lado oposto, e prosseguir através da mucosa, até o lúmen. A seguir, deve-se reintroduzir a agulha, do mesmo lado, através da mucosa e da camada muscular para emergir na superfície serosa do intestino. A sutura é amarrada firmemente e assim o próprio tecido se comprime. As suturas de Gambee reduzem a eversão de mucosa e podem diminuir o trançamento de material do lúmen intestinal até o exterior.

Sutura de Gambee é uma técnica útil na cirurgia gastrointestinal do eqüino, pela mínima formação de aderência e estenoses.

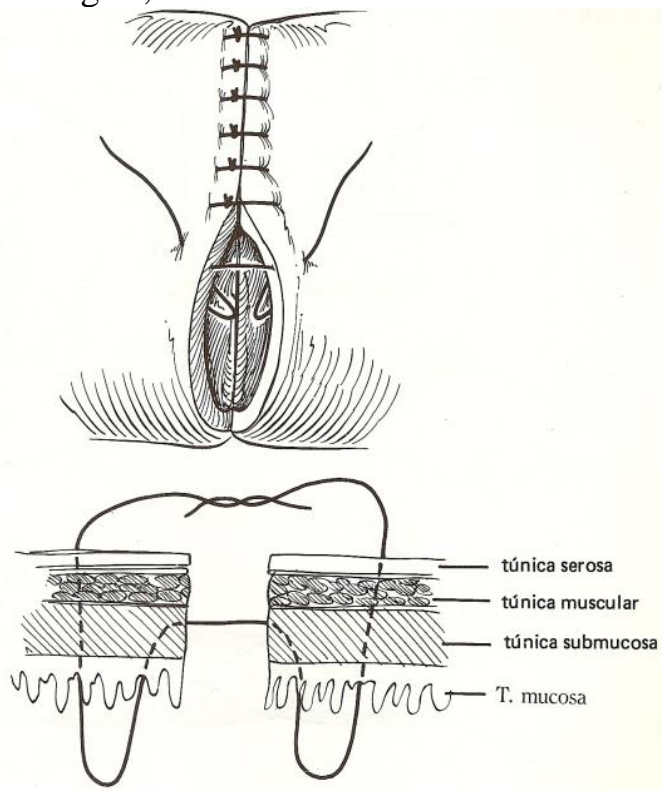

Figura 36. Sutura de Gambee.

\section{Sutura de Halsted}

Sutura de Halsted compreende essencialmente duas suturas de Lembert que estão paralelas uma a outra e amarradas de tal modo que o nó se encontra de um lado do ferimento (Figura 37).
Este modelo de sutura é resistente, aproxima bem e comprime muito pouco os tecidos, mais provavelmente estrangula o suprimindo de sangue muito mais que a sutura de Lembert interrompida. É muitas vezes referido como o modelo de sutura de escolha para os tecidos friáveis. 


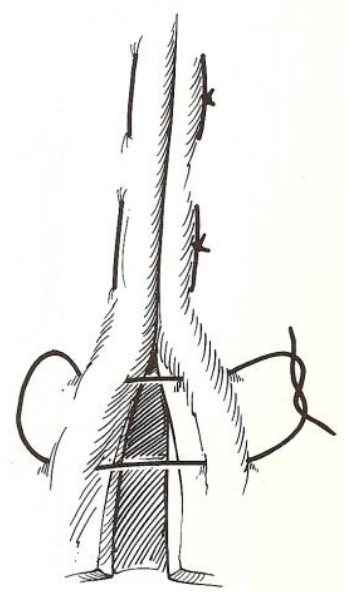

Figura 37. Sutura de Halsted.

\section{Sutura perto-longe-longe-perto}

Esta sutura encontra-se ilustrada na Figura 38. Esta sutura toma tempo para ser inserida, mas, é uma excelente sutura de tensão. A primeira pega é executada próxima ao ferimento, então passa por baixo do ferimento através das suas bordas em ângulos retos para emergir a uma distância relativamente grande na borda oposta do ferimento. A próxima parte da sutura consiste em cruzar por cima do ferimento até o lado original inserindo a agulha a uma distância maior da borda que o ponto original de entrada. A sutura então direciona-se para dentro do ferimento perpendicularmente às bordas do mesmo, cruza o ferimento emergindo próximo da borda no lado oposto. As extremidades do fio se encontram sendo então amarradas.

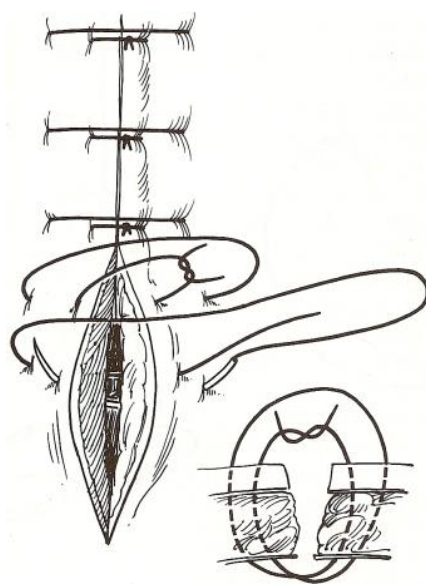

Figura 38. Sutura perto-longe-longe-perto.

\section{Suturas contínuas}

Suturas contínuas são aquelas em que o fio de sutura não é interrompido e os pontos são ligados uns aos outros. É feita inserindo-se a agulha através dos tecidos divididos, prendendo o primeiro ponto com um nó e depois continua passando e repassando a agulha e o fio através de toda extensão da ferida, prendendo a sutura final com um segundo nó. Assim, são aquelas que se praticam empregando um só segmento de fio do princípio ao fim da sutura. Esta sutura poupa tempo, mas não deve ser feita apertada demais, pois resulta em isquemia dos bordos tissulares.
A maior vantagem dos tipos de suturas contínuos é a velocidade da sutura. Os padrões contínuos utilizam menos material de sutura e minimizam os nós, reduzindo tanto o tempo cirúrgico como a quantidade de material estranho deixado na ferida. Além disso, as suturas contínuas formam um lacre maior à prova de ar $\mathrm{e}$ à prova d'água.

As desvantagens dos padrões contínuos são controle menos preciso da tensão da sutura e aproximação da ferida e os efeitos potencialmente desastrosos do rompimento da 
sutura (o rompimento da sutura em padrão contínuo pode levar à ruptura de toda a linha de fechamento). Além disso, os fios de sutura usados para fechamentos contínuos devem ser manipulados com o máximo cuidado.

\section{Sutura em ponto simples contínuo}

Uma sutura contínua simples consiste em uma série de suturas simples com um nó em cada extremidade. A sutura é contínua entre os nós, sendo a mais simples das suturas contínuas. Ela é aplicada nos tecidos que são elásticos e que não serão submetidos a uma tensão considerável.

Para iniciar a linha de sutura contínua simples, deve-se colocar uma sutura interrompida simples e amarrar o fio, mas cortar somente a extremidade que não se encontra presa na agulha. Assim, dado o ponto inicial, a agulha é introduzida em um dos lados da ferida, a uma distância que pode variar de 1 a 5 milímetros da borda e dirigida ao centro da mesma, para então penetrar no lado oposto, onde emerge a uma mesma distância da penetração, porém um pouco mais adiante e assim sucessivamente até o fim. As perfurações nas bordas do ferimento são executadas em ângulos retos em relação às bordas, mas a parte exposta da sutura atravessa a incisão diagonalmente (Figura 39). Para terminar uma sutura contínua, deve-se amarrar a extremidade do fio da agulha no último laço do fio que fica exterior aos tecidos.

Durante sua execução devemos ir fazendo uma tração moderada na extremidade livre do fio, com a finalidade de promover uma adequada aproximação dos lábios da ferida. Ela é indicada sempre que for desejada uma acomodação melhor dos pontos e, especialmente, certa elasticidade, e encontra indicação no fechamento da linha alba e do tecido subcutâneo.

Linhas de sutura contínuas simples proporcionam uma aproximação tecidual máxima e são relativamente resistentes a ar e fluidos, quando comparadas com suturas interrompidas simples.

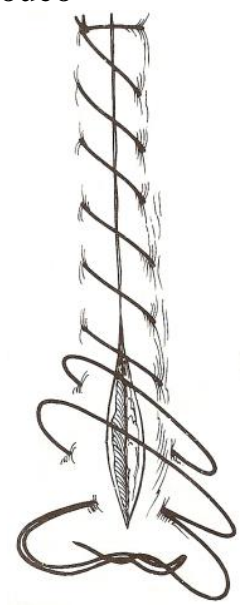

Figura 39. Sutura em ponto simples contínuo.

\section{Sutura festonada ou de Reverdin}

Também conhecida como sutura contínua ancorada ou de Ford, trata-se de uma modificação da sutura contínua simples. A penetração da agulha, depois de dado o ponto inicial, assim como sua saída, acontecem como na sutura contínua simples, só que antes de se realizar nova penetração, a agulha é passada pelo ponto anterior, ou seja, após se passar a agulha através dos tecidos, ela é passada por dentro do laço pré-formado e este é apertado (Figura 40). Este tipo de sutura é indicado quando houver certa resistência à aproximação das bordas da ferida, o que ocorre com certa freqüência na pele, pois o ponto passado não permite o relaxamento fácil da sutura conforme acontece na contínua simples. Nesta sutura a elasticidade e a acomodação ficam menores do que na contínua simples. 

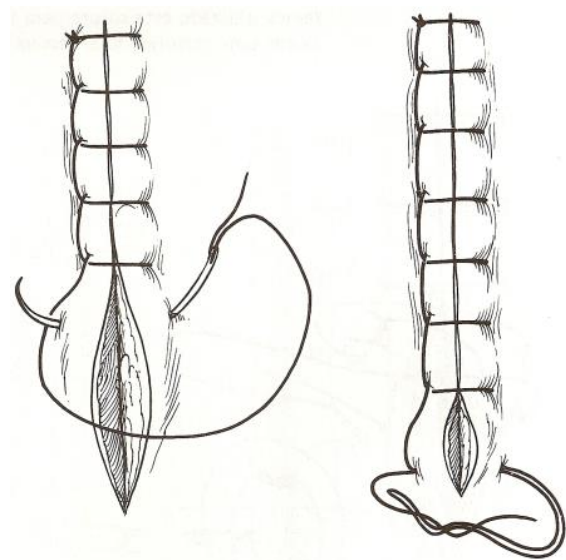

Figura 40. Sutura festonada ou de Reverdin.

\section{Sutura em "U" deitado ou sutura horizontal de colchoeiro contínua}

Aplicado o ponto inicial, a agulha é introduzida em uma das bordas da incisão, a uma distância variável, e dirigida à borda oposta, de tal maneira que a saída da agulha será à mesma altura da entrada, cruzando, perpendicularmente, a linha da incisão. A agulha é novamente introduzida na borda, mesma da saída, para

anterior (Figura 41). Possui a vantagem de não passar por cima da ferida, é muito resistente e rápida de fazer, oferecendo, porém, o inconveniente de não promover uma boa coaptação dos lábios da ferida. Muitas vezes é necessário empregar outra sutura, após esta, para eliminar o inconveniente citado.

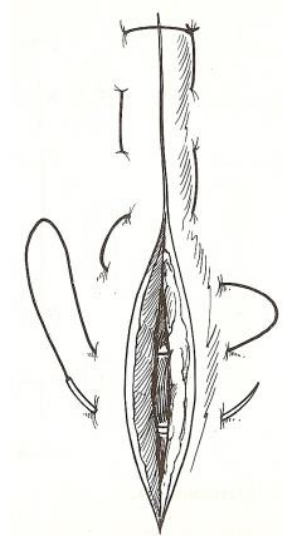

Figura 41. Sutura horizontal de colchoeiro contínua.

\section{Sutura simples contínua intradérmica}

É uma sutura contínua simples na qual a agulha é sempre introduzida na derme, de modo que a agulha penetra e sai sempre ao nível da espessura da pele, tornando-se, por isto, invisível após o fechamento. Ela é indicada quando se deseja uma cicatriz mínima, como nas cirurgias plásticas (Figura 42).

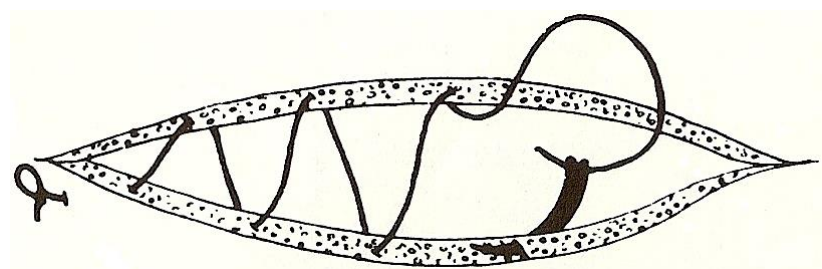

Figura 42. Sutura simples contínua intradérmica. 


\section{Sutura intradérmica em ziguezague}

Neste tipo de sutura a agulha penetra e sai sempre na superfície de corte da pele, tendo as mesmas indicações que a precedente, porém, com uma vantagem: é de mais fácil remoção.

A primeira parte desta sutura é disposta direcionando a agulha até o ápice da incisão na direção oposta da incisão (figura 43). A agulha é então revertida e conduzida por baixo da incisão.
O nó é amarrado, e desta maneira, será subcutâneo. O restante do modelo de sutura é executado conforme a sutura horizontal de colchoeiro, com a agulha cruzando a incisão em ângulos retos, avançando por baixo da derme paralelamente à incisão. Um nó semelhante aquele aplicado no modelo da sutura contínua termina a sutura, devendo também ser subcutâneo

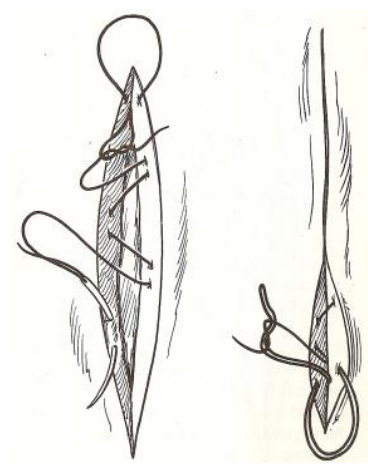

Figura 43. Sutura contínua intradérmica em ziguezague.

\section{Sutura de Schmieden}

Indicada para órgãos ocos, promove uma boa coaptação dos lábios da ferida. Depois de aplicado o ponto inicial, a agulha é introduzida na mucosa e dirigida à serosa, atravessando a muscular do órgão. A seguir é aplicada do lado oposto, seguindo sempre a mesma orientação: mucosa para serosa, e assim sucessivamente, sempre de dentro para fora (Figura 44). É uma sutura contaminante, seromucosa, razão pela qual exige uma segunda linha de sutura, que seja invaginante. Por promover boa coaptação dos lábios e melhor cicatrização, ela é superior à de Connel (ver a seguir).

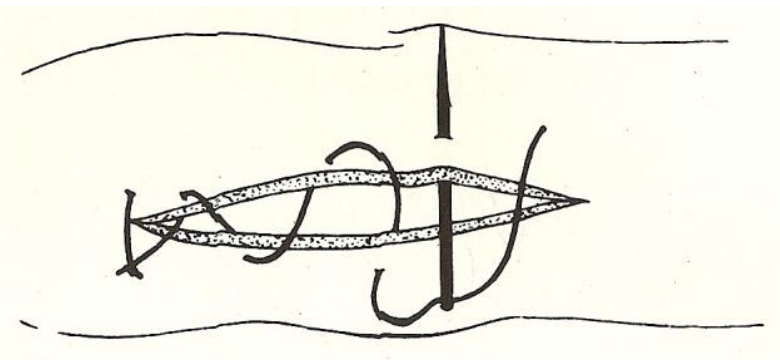

Figura 44. Sutura de Schmieden.

\section{Sutura Cushing ou D'Apolito}

É uma sutura invaginante, seromuscular e realizada em orgãos ocos, indicada para complementar a sutura de Schmieden. Este é um método de sutura onde as perfurações são feitas paralelamente às bordas do ferimento (Figura 45). Conforme a sutura é posicionada, ela penetra a serosa, a muscular e a submucosa, mas não atravessa a membrana mucosa, consequentemente, não entra no lúmen da víscera. Assim, depois de feito o nó inicial, a agulha é introduzida na serosa até a muscular e dirigida para sair na mesma borda, um pouco mais adiante, em progressão paralela ao lábio da ferida. A agulha, em seguida, cruza a incisão em ângulo reto e penetra no lábio oposto da incisão, à mesma altura da saída e se procede do mesmo modo que na ação precedente.

A sutura de Cushing inverte a mucosa e aproxima a serosa. É geralmente utilizada como ponto externo num fechamento de dois planos, podendo ser rapidamente executada. 


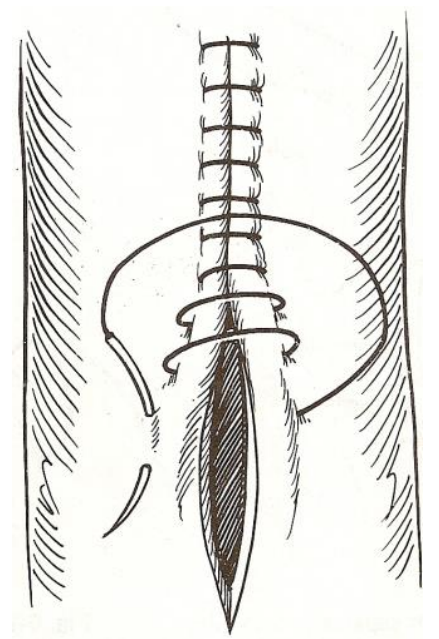

Figura 45. Sutura de Cushing.

\section{Sutura de Connel}

É praticada do mesmo modo que a sutura de Cushing, sendo que a única diferença reside no fato de que enquanto a de Cushing é seromuscular, a de Connel é seromucosa (entra no lúmen). Esses padrões são usados frequentemente para fechar órgãos ocos, pois causam inversão tecidual e proporcionam selagem impermeável.

$\mathrm{Na}$ sutura de Connell a agulha deve avançar paralelamente à incisão e ser introduzida na serosa, atravessando as superfícies muscular e mucosa. A partir da superfície profunda (lúmen), deve-se avançar a agulha paralelamente ao longo da incisão e retorná-la, através dos tecidos, até a superfície serosa. Quando fora da víscera, devese passar a agulha e o fio de sutura através da incisão, perpendicularmente, e introduzi-los em um ponto que corresponde a altura do ponto de saída no lado contralateral. Assim, quando se aperta o fio de sutura, inverte-se a incisão (Figura 46).

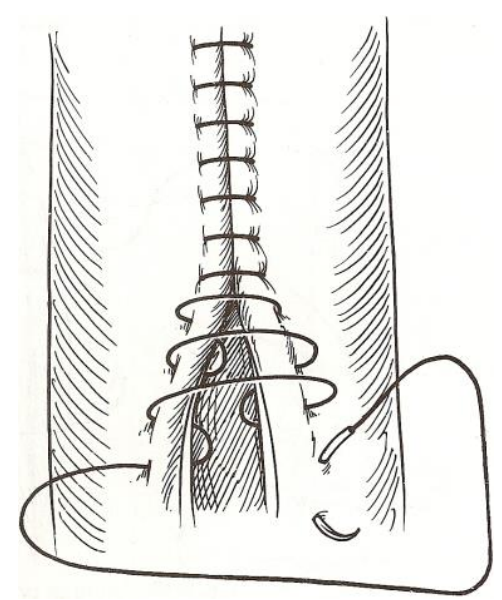

Figura 46. Sutura de Connell.

\section{Sutura de Lembert contínua}

A sutura de Lembert também pode ser efetuada de modo contínuo. O mesmo espaçamento é realizado como o da sutura interrompida (Figura 47). A sutura é habitualmente utilizada tanto para o fechamento do intestino ou do útero, e requer menos tempo que a sutura interrompida. 


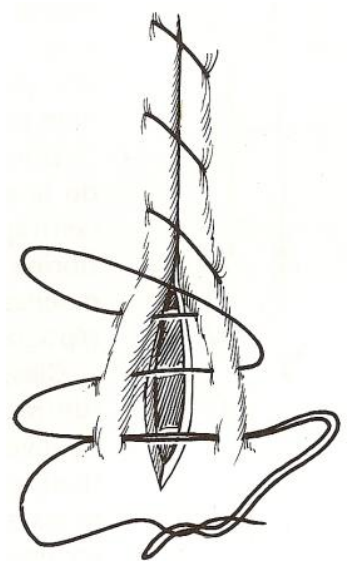

Figura 47. Sutura de Lembert contínua.

\section{Sutura em bolsa}

É um tipo de sutura contínua posicionada em círculo ao redor de uma abertura, entretanto a sutura é amarrada quando já foi concluída a circunferência inteira do círculo (Figura 48). Tal como a sutura de Cushing, esta sutura não penetra o lúmen. Outra camada de suturas pode ser aplicada acima da bolsa, tanto em forma de uma outra sutura em bolsa como em uma série de suturas de Lembert. A sutura em bolsa é utilizada para chulear uma abertura do trato gastrintestinal que elimina gás e que fora produzida pela punção feita por uma agulha ou trocater. Também pode ser usada para estabilizar cânulas ou fístulas permanentes.

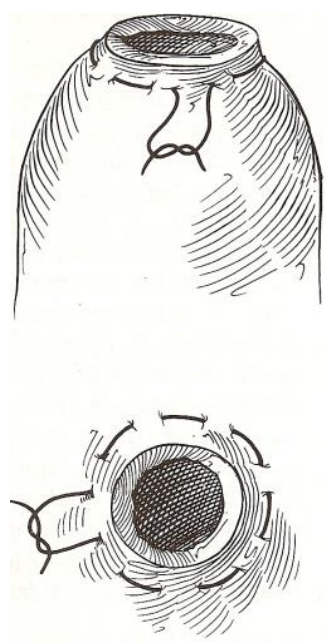

Figura 48. Sutura em bolsa

\section{REFERÊNCIAS}

ANNIS, J. R.; ALLEN, A. R. Atlas de cirugía canina. Tradução de: Irene Joyce Blank e Graciela Gallegos Gómes. 1. ed. México: União Tipográfica Editorial HispanoAmericana (UTEHA), 1975. 222 p.

BOJRAB, M. J. Técnicas atuais em cirurgia de pequenos animais. Tradução de revisão científica de Paulo Marcos Agria de Oliveira. 3. ed. São Paulo: Roca, 2005. 896 p. Tradução de: Current techniques in small animal surgery.
FOSSUM, T. W. Cirurgia de pequenos animais. Tradução de Paulo Marcos Agria de Oliveira. 2. ed. São Paulo: Roca, 2005. 1390 p. Tradução de: Small animal surgery.

HARARI, J. Segredos em cirurgia de pequenos animais: respostas necessárias ao dia-a-dia em rounds, na clínica, em exames orais e escritos. Tradução de: Augusto Langeloh et al. Porto Alegre: Artmed, 2004. p. 77-81. Tradução de: Small animal surgery secrets.

HICKMAN, J.; WALKER, R.G. Atlas de cirurgia veterinária. Tradução de Homem 
Israel Ferreira. 2. ed. Rio de Janeiro: Guanabara Koogan, 1983. 236 p.

LAZZERI, L. Fases fundamentais da técnica cirúrgica: diérese - hemostasia - síntese. São Paulo: J. M. Varela, 1977.190 p.

LEONARD, E. P. Fundamentals of small animal surgery. Philadelphia: W. B. Saunders Company, 1968. 269 p.

SLATTER, D. Manual de cirurgia de pequenos animais. Tradução de Adriana de Souza
Coutinho et al. 3. ed. Barueri, SP: Manole, 2007. v. 1. Tradução de: Textbook of small animal surgery.

TURNER, A. S.; MCILWRAITH, C. W. Técnicas cirúrgicas em animais de grande porte. Tradução de Cristina Pozzi Redko. 1. ed. São Paulo: Roca, 1985. 341 p. Tradução de: Techniques in Large Animal Surgery. 